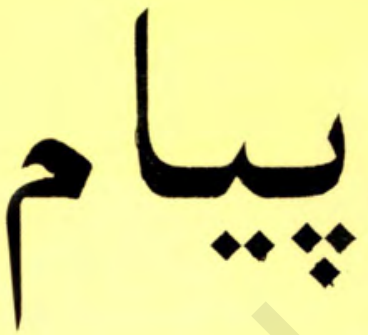

قاصد سنائى عليه الرحمه

اثر : مرحوم مرزا محمد نعيم ((قاصد))

ناشر : انجنير سيد ظاهر شاه (سلام)) 


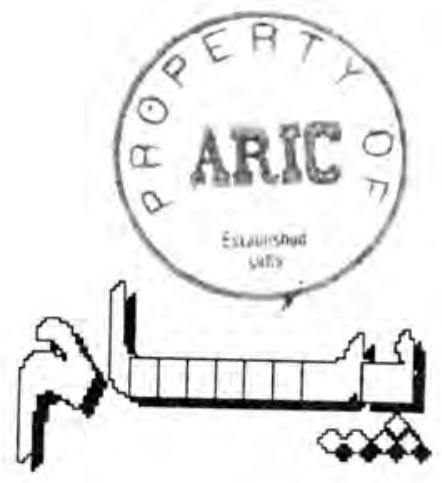

قاهص سنايي عليه الرحمه

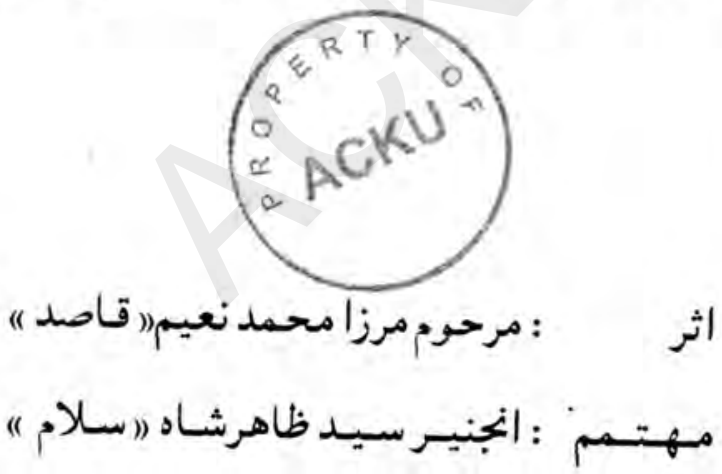

AFGHANISTAN CENTRE AT KABUL UNIVERSTY

AFGHANISTAN CEN

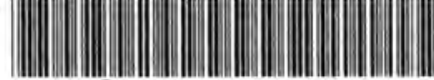

3 ACKU 000078559 


$$
\text { بسم الله الرحمزن الرحيم }
$$

$$
\begin{aligned}
& \text { مشخصسات كتاب } \\
& \text { : بيامقاصد : } \\
& \text { : مرزا محمد نعبيم " قاصد " }
\end{aligned}
$$
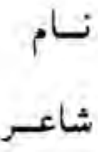

$$
\text { تاثيرير }
$$

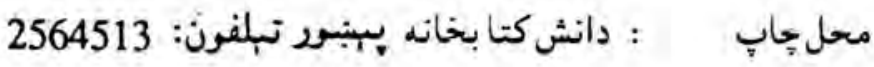

$$
\text { IrVV: : }
$$




\section{بسـمة تعـالى}

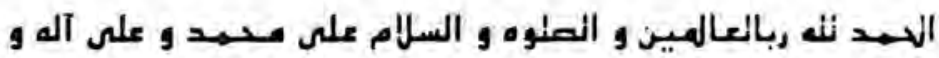

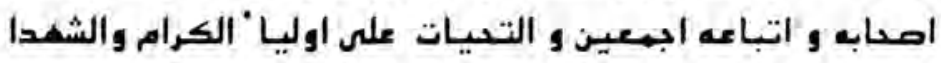
والصالهين

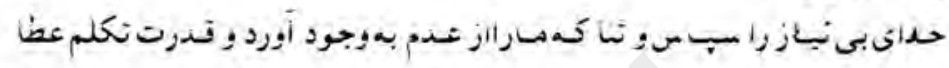

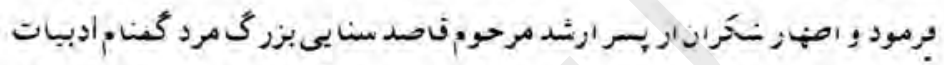

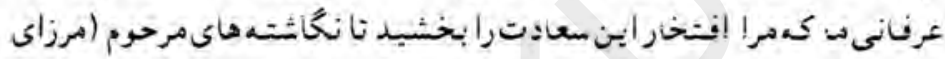

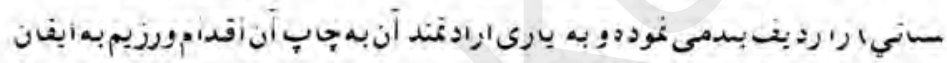

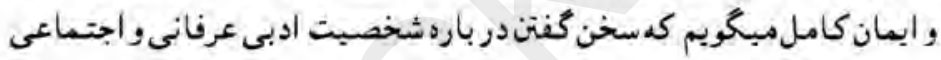

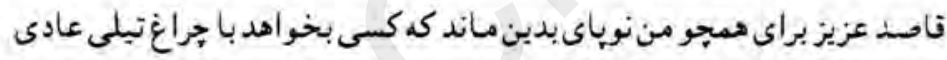

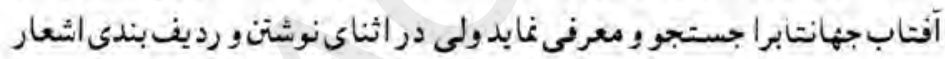

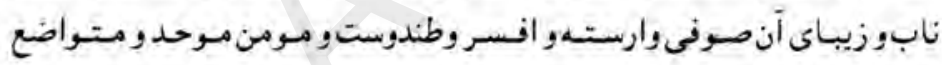
احساساتدرونى ام:

ور اندرونمسن خســتهدل لندانمكيسـست

كمن خموشسم, واودر فغانودر غورغاست

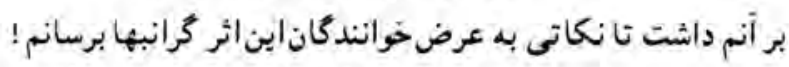

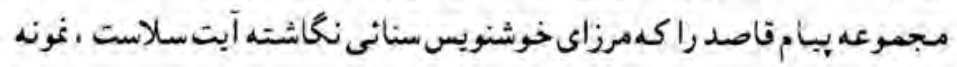




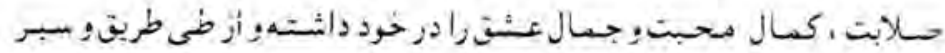

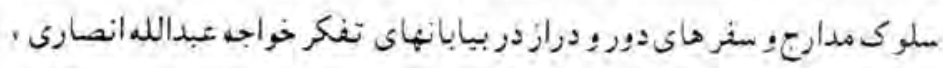

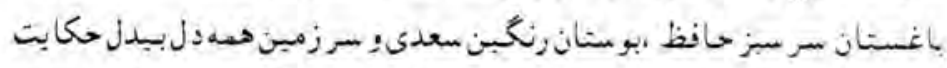

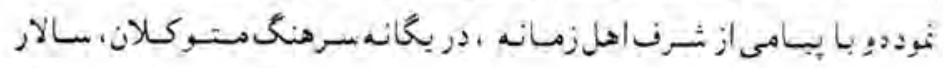

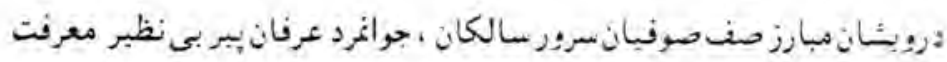

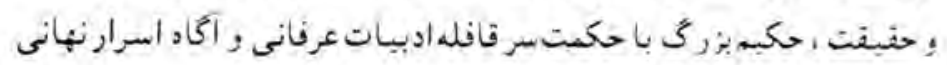

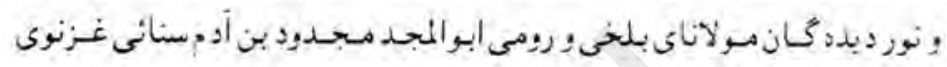

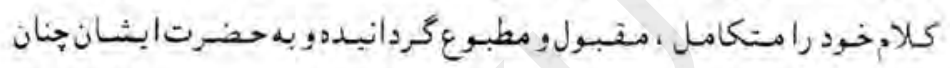

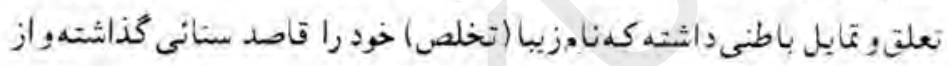

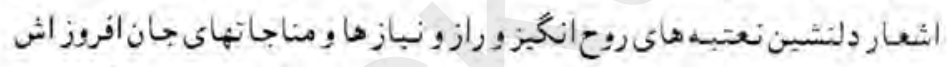

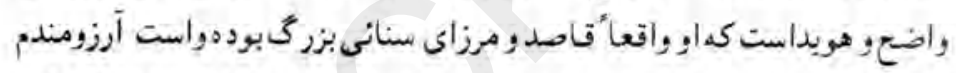

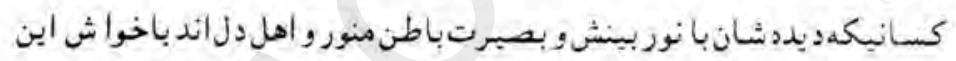

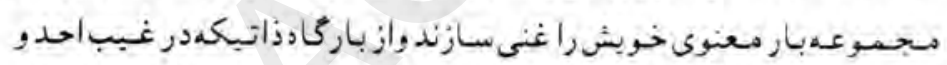

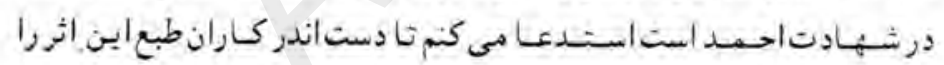

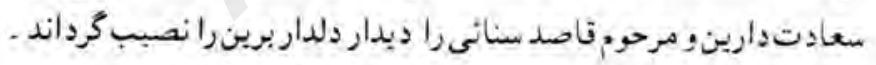
رمن اللهالتوفيب

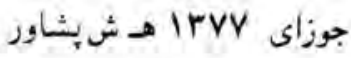

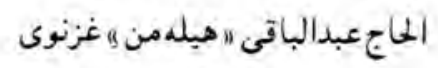


تاج بخش سروران و جارهء بـ جاره كان

$$
\text { اي اميد نااميدان وى يناه بى كسان }
$$

رو بذركاهت نهاد متكيه، هر نأتوان

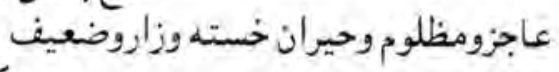

مفلس ورمانده حالم بس يريشان و زبون خذ بلطفى يا الهي دست ياس عاجزان

تحفه جز عصيان ندارم لايق غفاريت كن قبولش از كرم از من ستان اين أرمغان

عاصى و شرمنده ام از جرم خود بس منفعل فيل عفو فرما بحُخر از من خالق كون و ونكان

منزلم دوزست و من كم توشه و باربمران

$$
\text { غير فضلت نيست رهبر يبش رويم در سفر فرئ }
$$

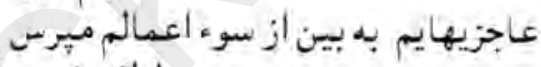
لطف خود بنغخر ميين افعال زيشت ناكسان

مويهايم شد سفيد و روسياه كارم زيان

$$
\text { قامتم خم كثت و كردارم نشد يكد مرسا }
$$

نفس و شيطلان از دو جانب يكة و تنها منم دشمنان اندر كمين مشفذار منرا ور ميان

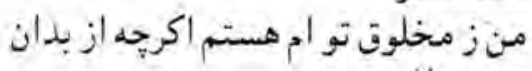

$$
\text { رحم كن يا رب مرا در ذيل نيكانت شمار }
$$

خالقامن را تو كردى خلق بي سعي و طلب

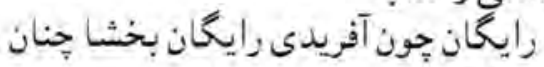

درگهءء ويحر نما تا من شوم آنجا روان

$$
\text { از دو خود گ مر برانى رهنمون شو بنده را }
$$$$
\text { قابل عفو كريمى كر نيم از جرم كم }
$$

جرم عالم را بدوشم كن به بخشيا بعد ازان

انتظار رحمتت دازد تو هستى مهربان

$$
\text { در حريم بي نيازى قاصد از روى نياز }
$$




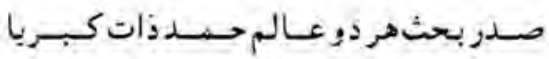

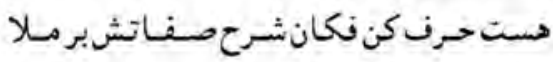

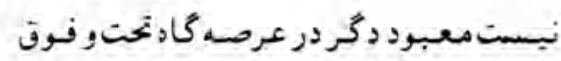

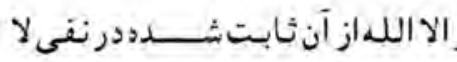

جـملهمـوجـودات عـالمدورسـريركـاينات

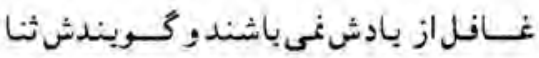

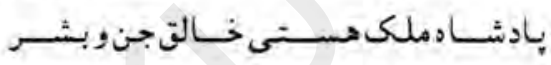

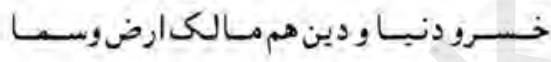

$$
\text { واحسد و يكتــا وبيـجـــون بىنبـاز ولا يزال }
$$

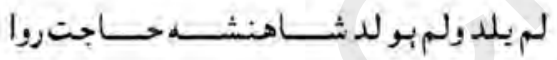

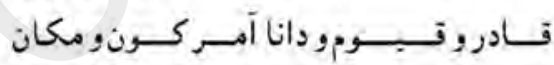

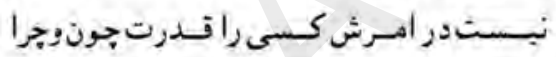

عــادل وبازل امــــــرخلقور ربالعــالمبن

لطفاوخالى زمسفصد عـدل ود ادشبى ريا

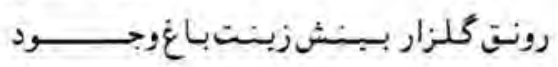

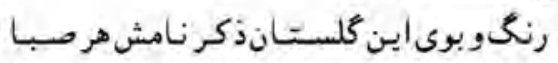




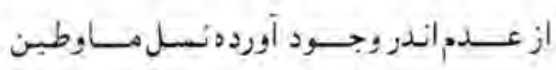

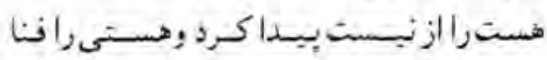

$$
\text { جسم انسـاندراه-جسم كردم:كز بكفطره أب }
$$

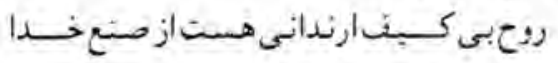

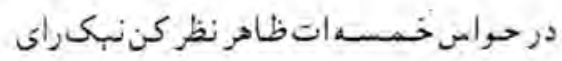

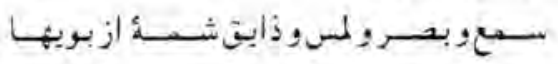

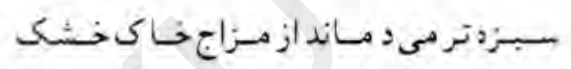

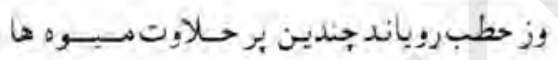

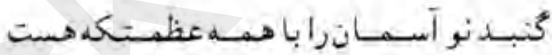

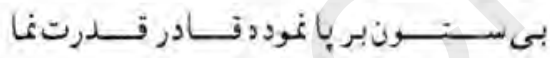

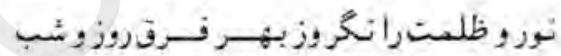

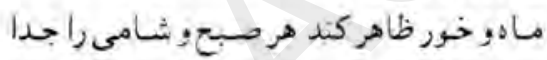

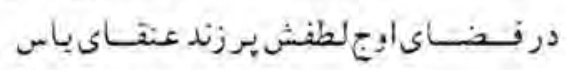

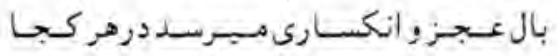

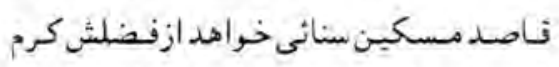

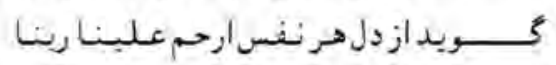




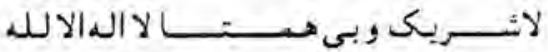

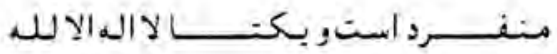

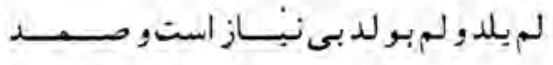

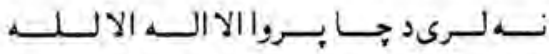

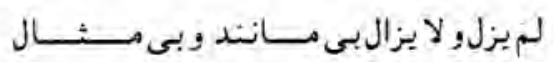

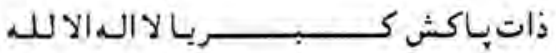

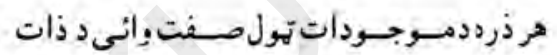

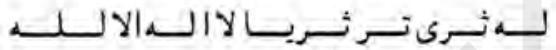

$$
\text { همرحسنورهبرحسبم وصفذاتاوتـديم }
$$

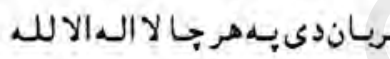

$$
\text { هم ســبعدى هم بصـير هم عـالمدى هم خبـيـر }
$$

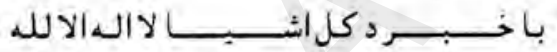

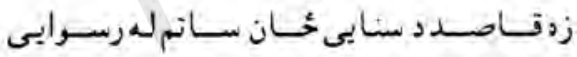

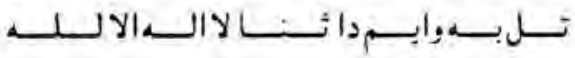


بردرتيا رب خـجل باجـرموعصـبـان أمـدم عـاجزمو زبهـرعـفو عـببـو نقـصـان آمـدم

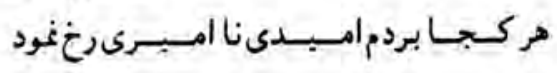

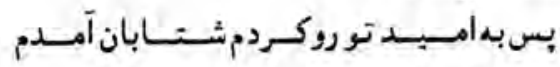

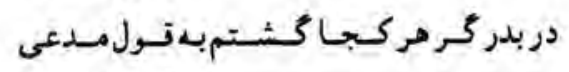

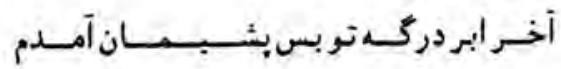

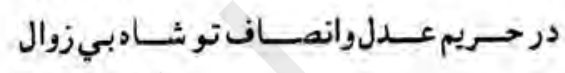

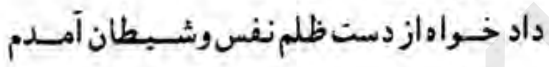

$$
\text { رحزنى هاكـردهامسـردادهعـصـيـانمنم }
$$

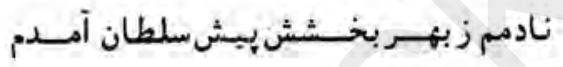

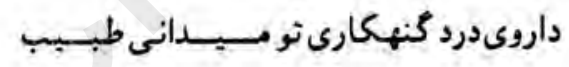

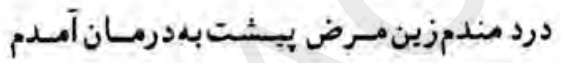

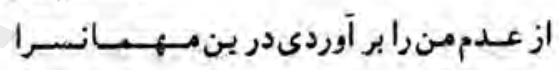

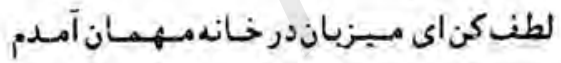

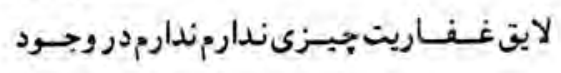

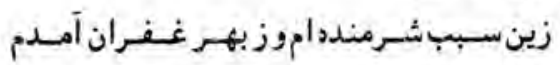

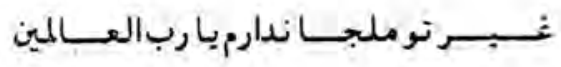

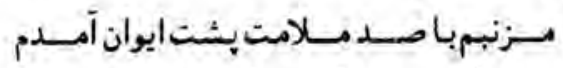

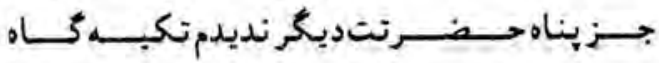

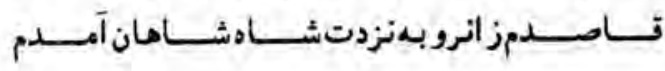




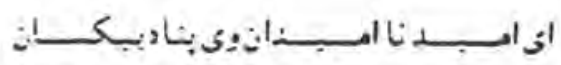

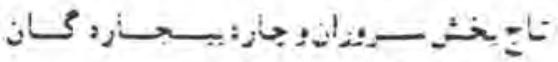

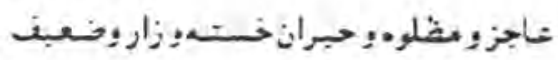

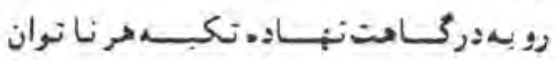

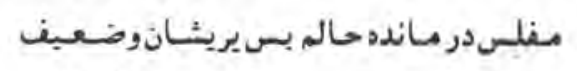

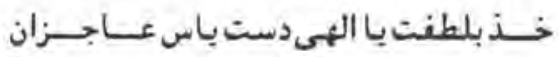

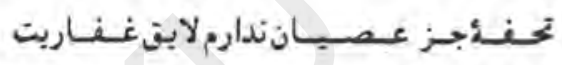

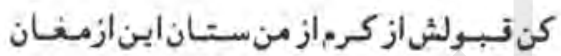

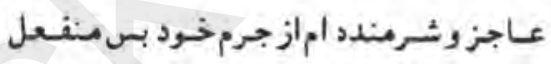
عفو نرمـا وكذار ازمن خالق كونو مكان

غبير نضلت نيستر رهبر بيشـرويمدر سفر

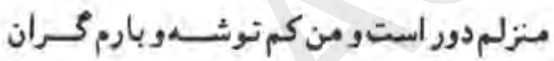

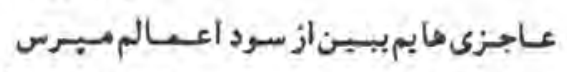

لطفخود بنكر مبتبن افعسال رشت ناكسـان

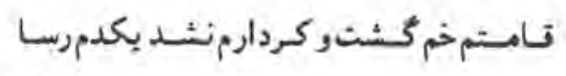

مويهايمشـدسفيــورورسيـاهكارمزيان

نفسورشـيطان ازدوجـانب يكهو تنهـا منم

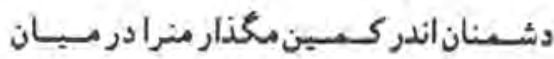




\section{رحم كن با زبمـــادزذذيل نبكانتثثـــار}

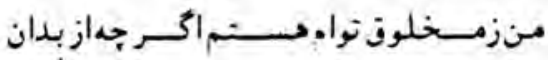

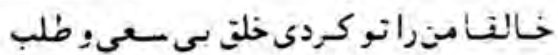

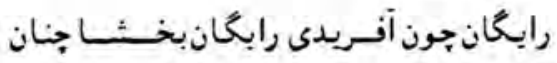

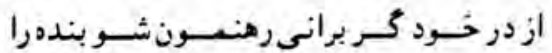

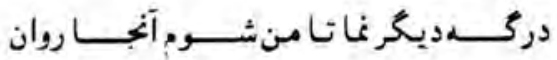

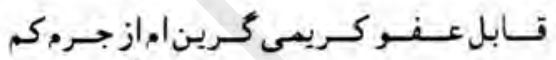

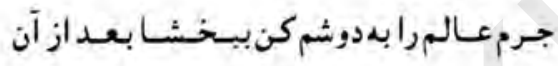

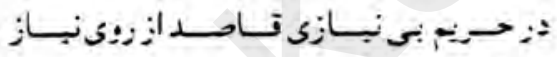

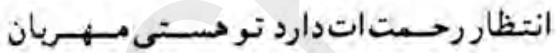




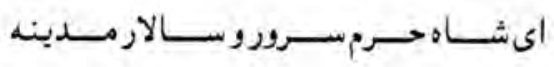

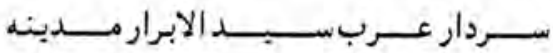

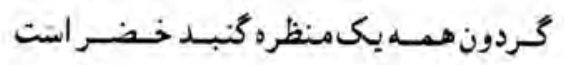

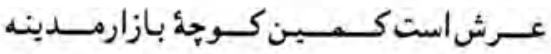

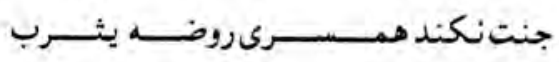

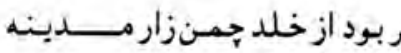

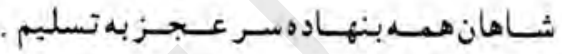

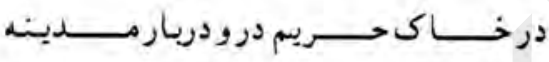

$$
\begin{aligned}
& \text { خــوبان جـهـــان جـمله خـريدار توهـــند }
\end{aligned}
$$

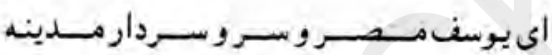

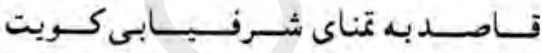

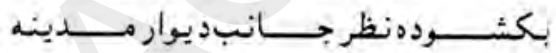




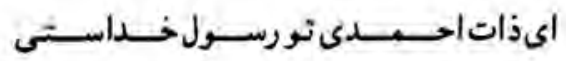

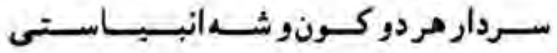

$$
\text { تُور جراغ عـــالم وخـــورشـــــــــــاينات }
$$

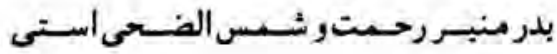

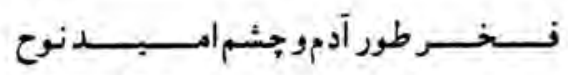

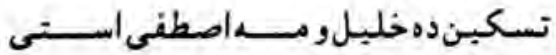

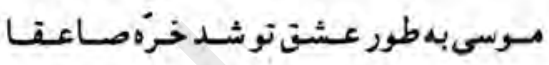

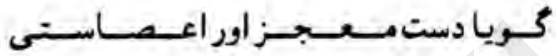

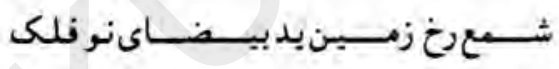

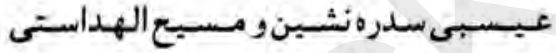

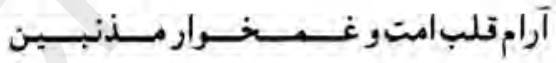

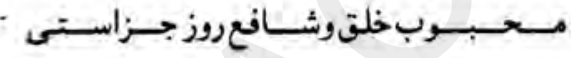

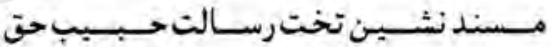

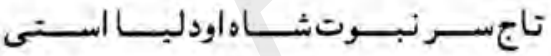

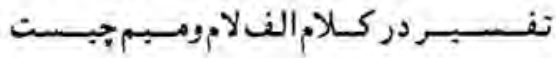

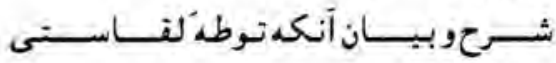

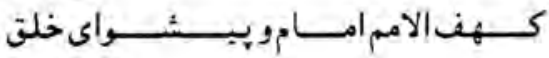

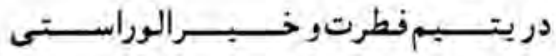

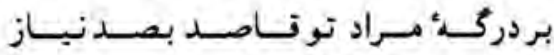

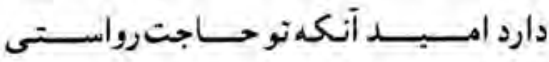




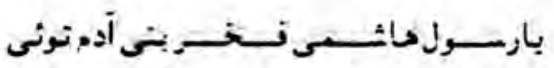

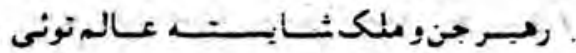

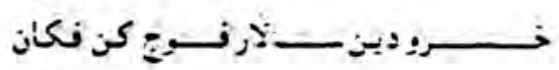

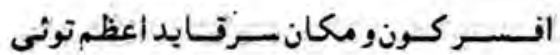

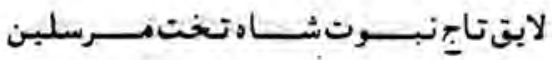

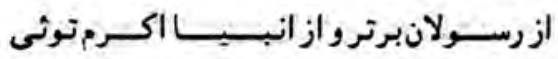

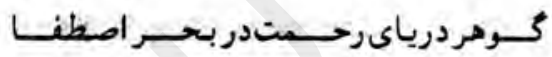

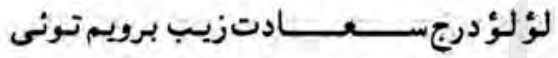

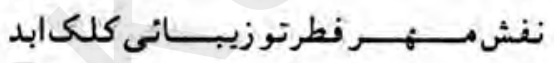

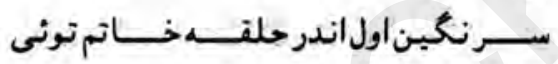

$$
\text { درد بـــــــــان ادباستـــــاد دانشـحاهراز }
$$

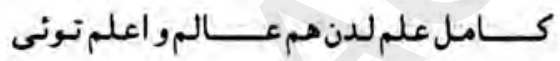

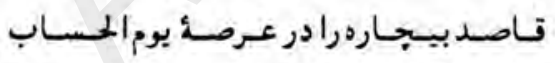

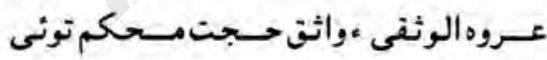




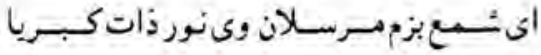

خورشبداز روبت خجل وصف جسالتر الضحى

$$
\text { سر دفتر كوثن ومكان مفصـود حرفكن فكان }
$$

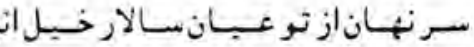

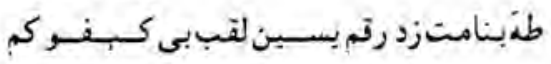

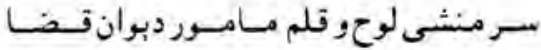

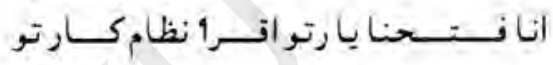

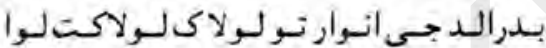

$$
\text { روح الامسبن بيكندرت تاج لعــــبر سـرت }
$$

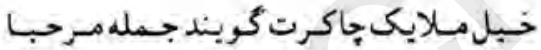

شـاهنثـا هدنيـا ودينمستبـوبر ربالعـالمين

دارى همس زير نخين أز مسرش تاتحت الثـرا

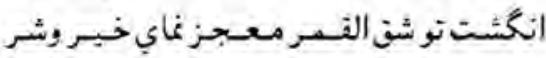

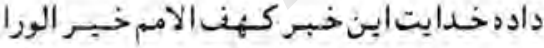

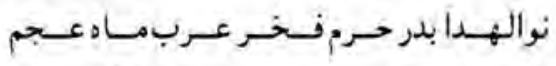

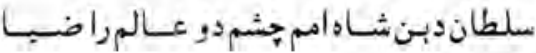

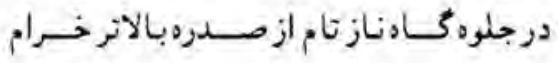

شد قابو قوسينا تمفامرشر مجبيدتزيريا 


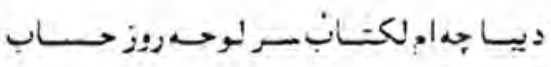

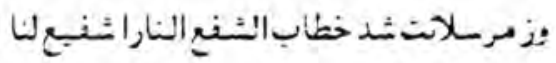

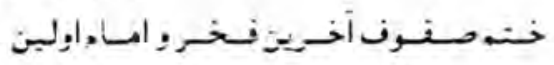

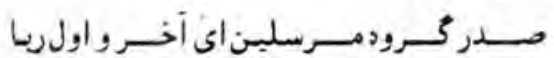

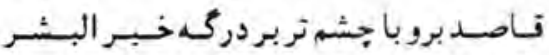

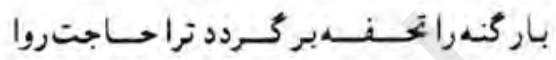


ايىصـدرخـاص انبـــــا صلو على صلو على

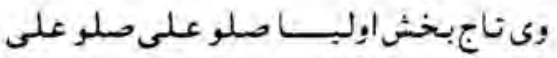

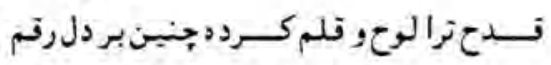

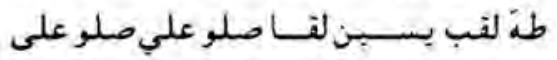

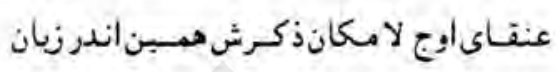

صلـو على صلو على صلو على صلو على

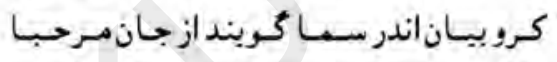

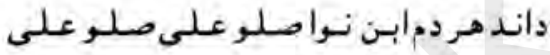

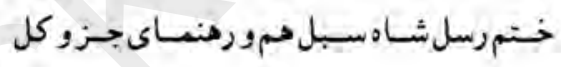

اي مـرســلان را مـــــــدا صلو على صـلو على

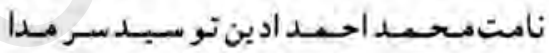

ذات نو مـــا جـدا مـجــــا صلو على صلو على

$$
\text { تو سـرورورسـالار مـاحم رحبر وغــخـوارما }
$$

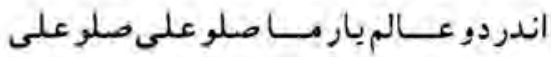

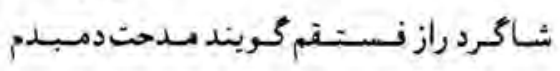

شمس وقـمر ارضونسما صلو على صلو على

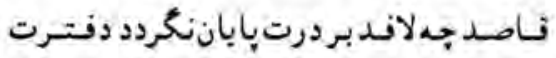

$$
\begin{aligned}
& \text { كردهاستوصفت را خدا صلو على صلو على }
\end{aligned}
$$




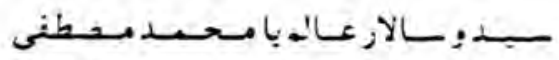

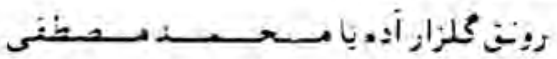

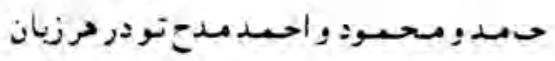

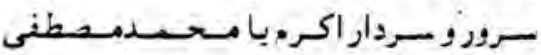

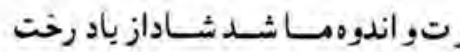

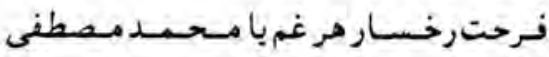

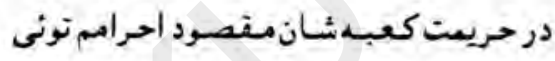

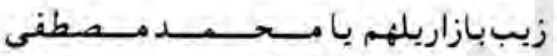

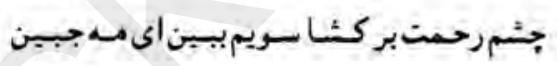

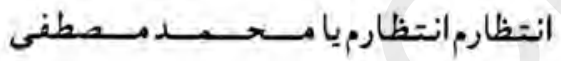

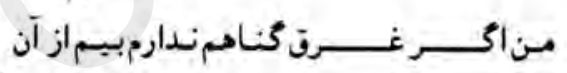

جون تونى غـخوار محكم يا مسحمد مصطفى

$$
\begin{aligned}
& \text { تـاصد مسـكيث جنين كـوبد كهنسخر اولين }
\end{aligned}
$$

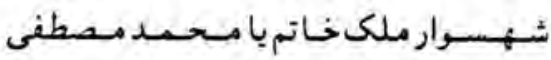




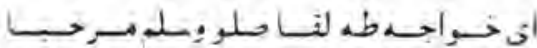

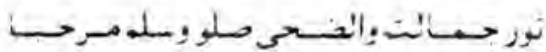

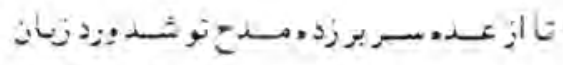

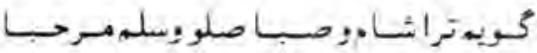

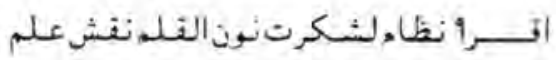

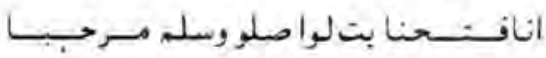

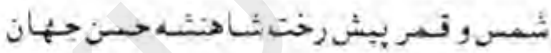

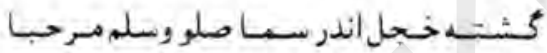

برعـرصبه عـرش برين نا بانهـادئنازنين

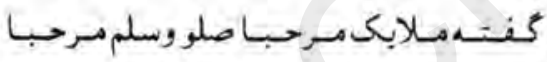

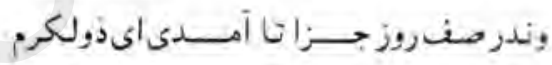

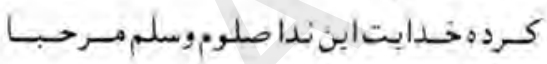

هردمبخاك روضساست تاصد رساند ايندعا

بـدرالدجى صل على صلو وسلم مـــــــــا 


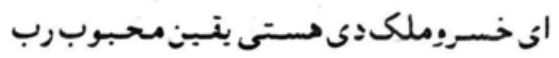

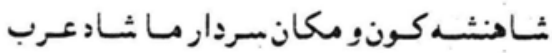

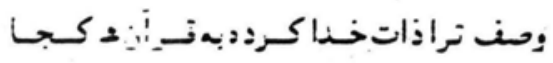

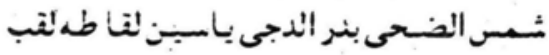

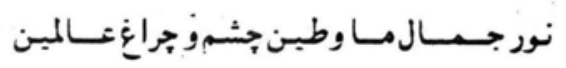

روشنز تو عـرش بريسن مـاهشـبــــــــانلقب

$$
\text { شـاهنشـهنيكو سـيـر كردى عـيـانشق قـمـر }
$$

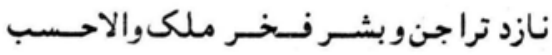

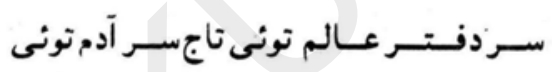

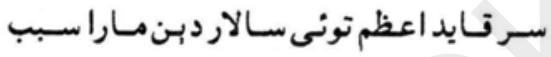

$$
\text { صـدر نزراد هاشــى جــد حســن بوالفـــــى }
$$

برهر دو عـالم حـاكسمى وكى ســـــد عـالى نسب

$$
\text { دركسشـور ملكى حسرمزيبــد ترا تاج وعلم }
$$

مثلت عربنى در عجم خوبان به وصفت روزو شب

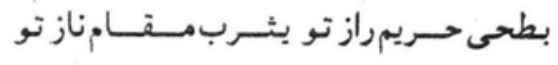

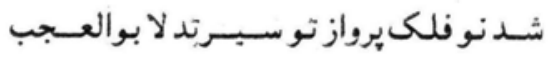

$$
\text { اندر صف روز جـزا هستـى تو بسمــصـد روا }
$$

كهف الامم خيرالورا عـاصى منم حـاجت طلب

$$
\begin{aligned}
& \text { تـاصـد ازينهم مـنفعل افتـاد حيـرانو خـجل }
\end{aligned}
$$

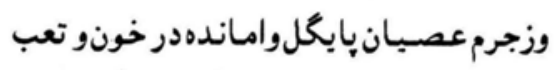




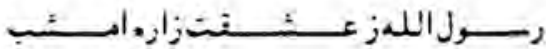

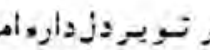

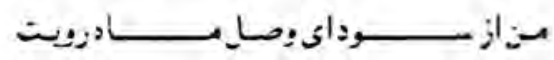

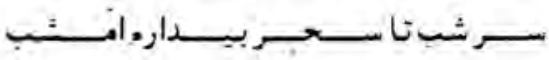

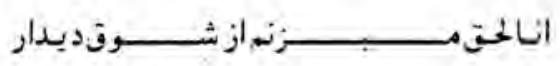

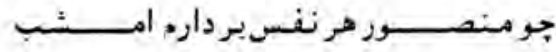

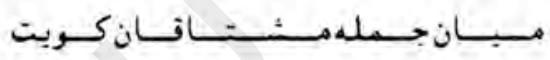

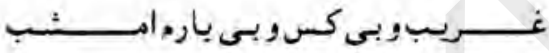

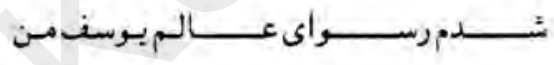

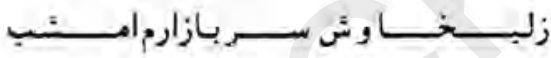

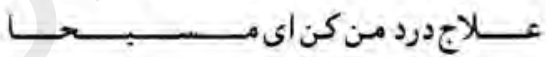

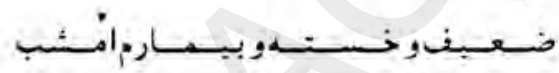

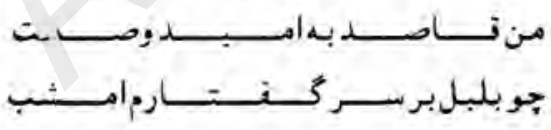




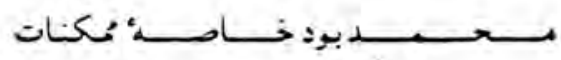

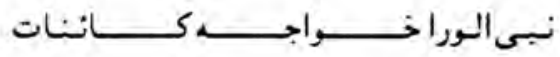

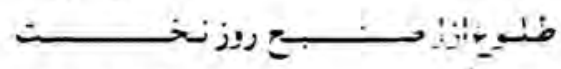

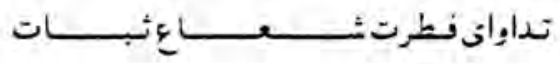

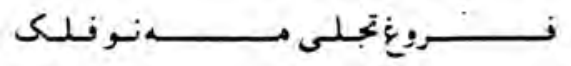

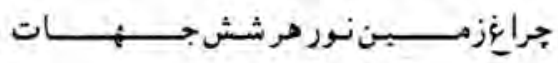

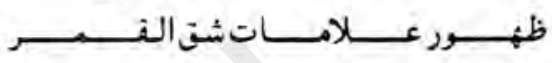

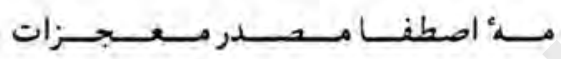

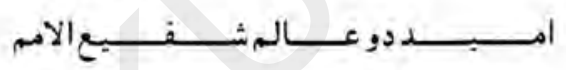

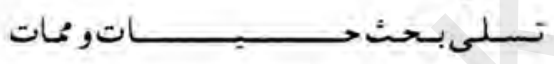

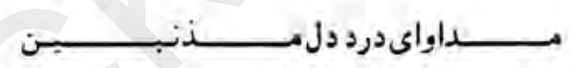

رافع ســــــــــــات

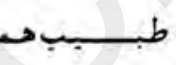

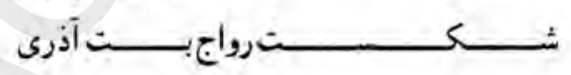

خ آو

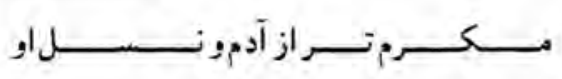

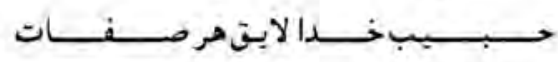

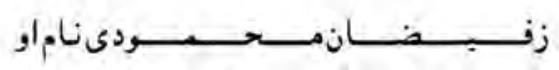

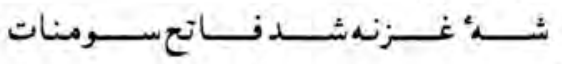

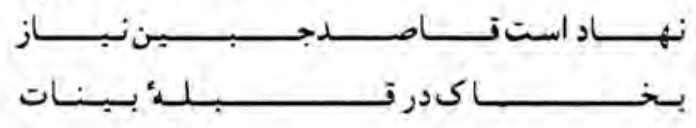




\section{آنكه:ر دنيـا وعنبي رهبرو, غمخوار ماست}

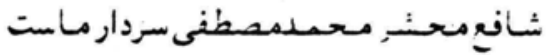

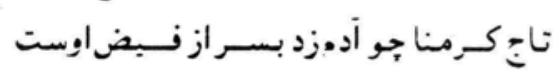

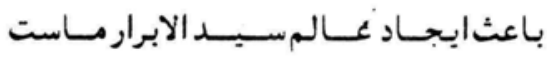

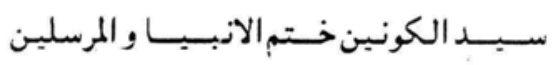

سر نوشت لوح فطرت احسمـد مـخـــار مـاست

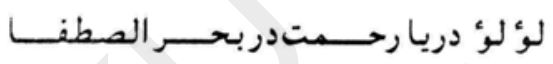

لعل بـى همتـاى وحـدت كُوهر شـهـوار مـاست

$$
\text { تابو تسكين همـهـهـيل خـروه مـذنبـين }
$$

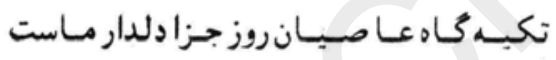

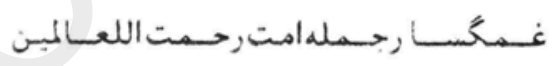

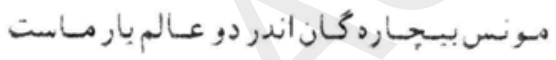

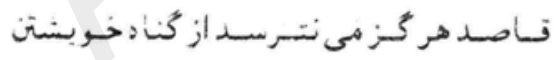

$$
\begin{aligned}
& \text { زانكهدر محشر شفاعت خواه مـا بأدار ماست فئست }
\end{aligned}
$$




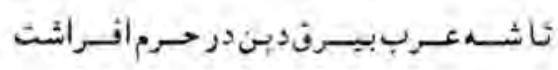

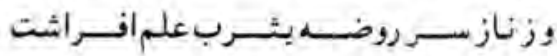

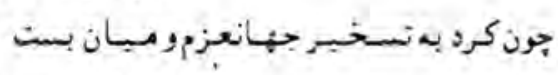

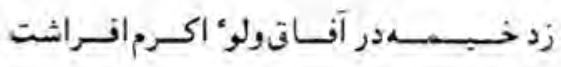

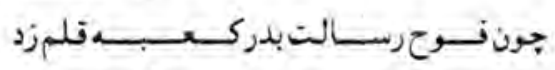

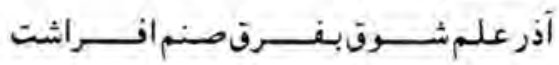

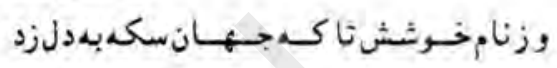

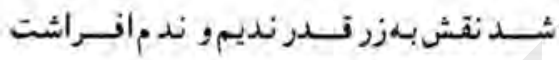

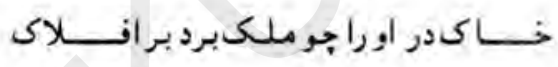

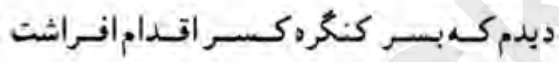

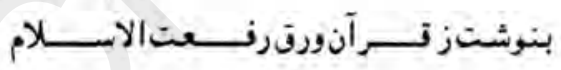

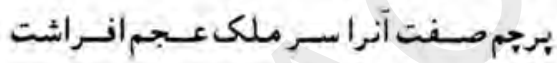

$$
\text { جبـر بيل جوشـد حـامل وحى وخط ونرمـان }
$$

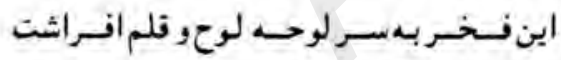

$$
\begin{aligned}
& \text { وصـفشبمزبانهـاست ولىدرصف عـشـاق }
\end{aligned}
$$

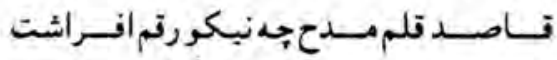




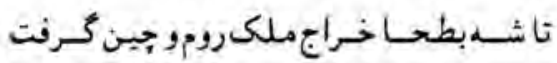

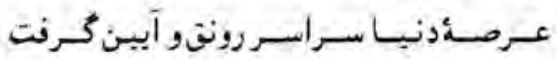

$$
\text { بود عــــرى روضـهـيثـرب بوصلش انتظار }
$$

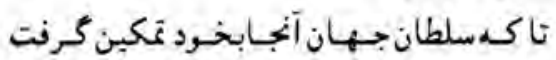

$$
\text { كعبهاز لطفث هبى ناليد وكفت از لطفرب }
$$

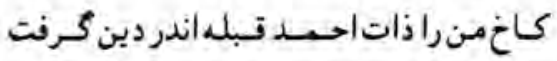

$$
\text { عـالمى اندرضـلالمت بود مسحسوكنر وجـهل }
$$

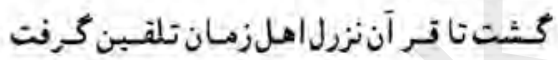

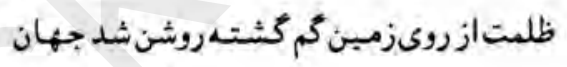

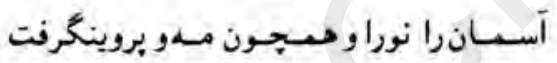

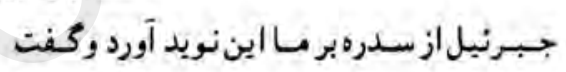

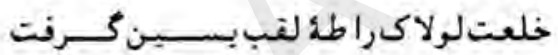

بر رواتش خواند تـاصد صـد درود صـدسـلام

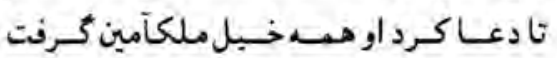




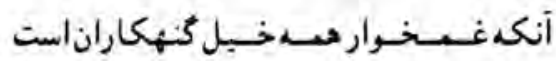

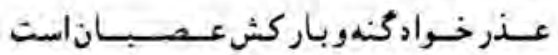

$$
\text { سرور حردوجــبان احمـد مرسل كمبدكـون }
$$

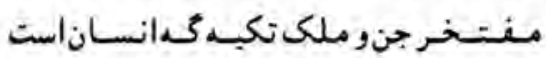

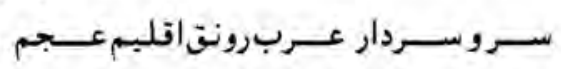

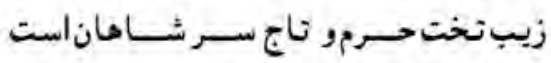

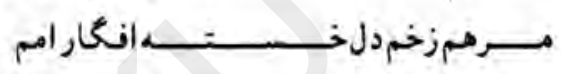

داروى درد و غـــــاى تن بيــــــــــــان است

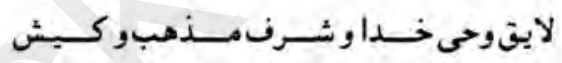

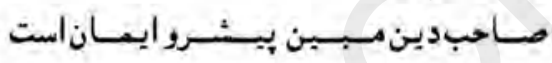

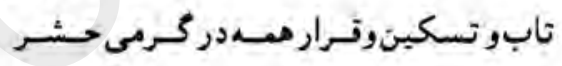

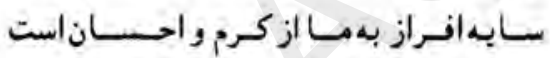

$$
\text { وقتوزنعـــل بسنجشمــزانو حسبـاب }
$$

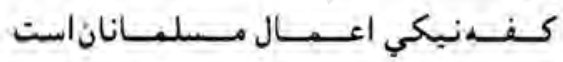

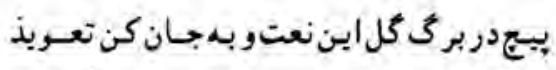

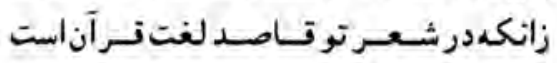




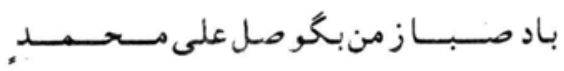

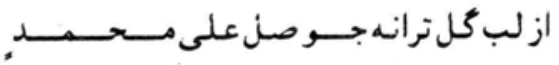

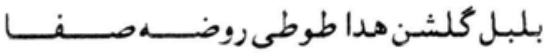

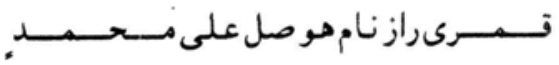

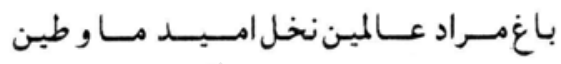

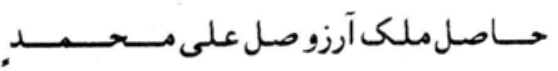

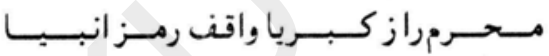

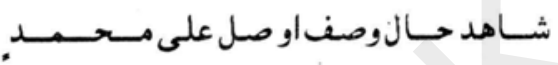

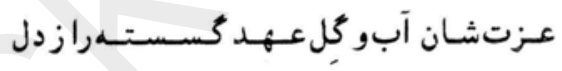

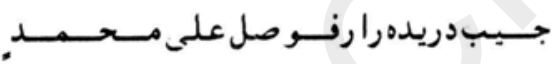

طاهر سـدره آشـــــانصــــوهبـاغكن فكان

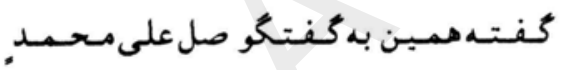

سـبزهو كشت كـايناتنون جـــاد وهم نبـات

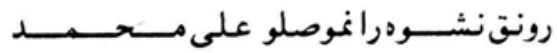

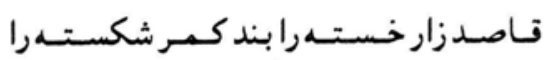

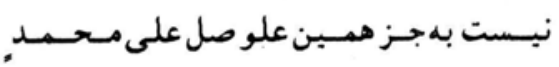




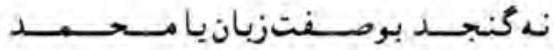

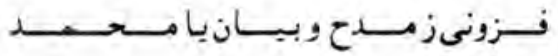

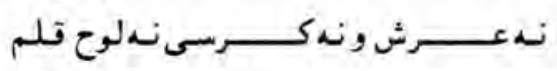

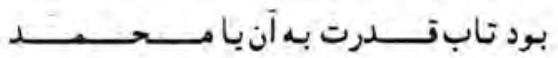

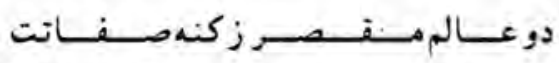

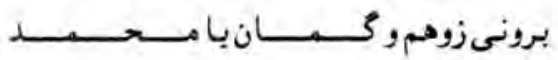

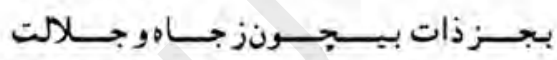

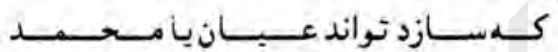

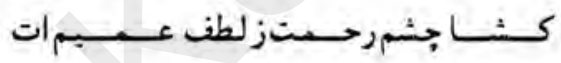

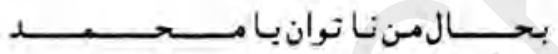

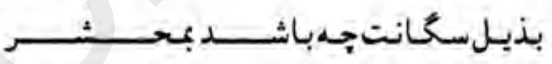

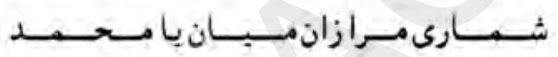

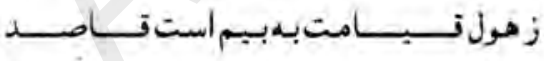

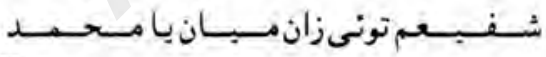

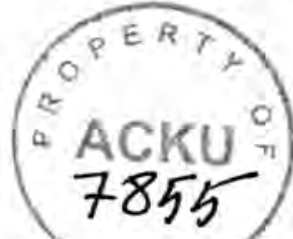




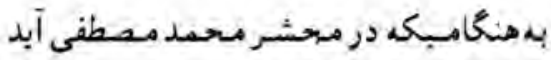

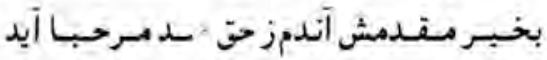

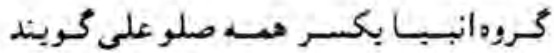

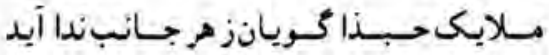

يـود انـدر عنـاناودمرورح الامـــــــن بـويـان

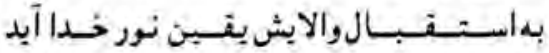

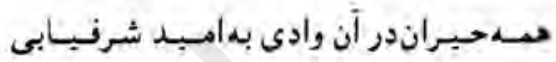

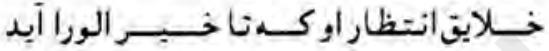

تمامعـالمو آدم به حســرت جشــــــر راهش

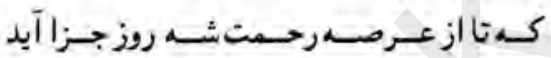

حسبـاب حســريان مسعلل به تشـريفتمنايش

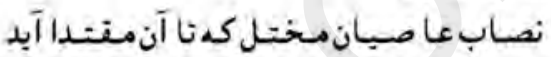

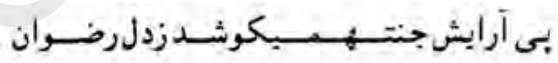

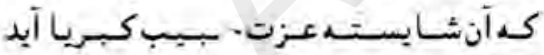

خـجل از برتو حسنش شـود حسورانوغلمـانان

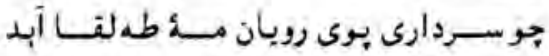

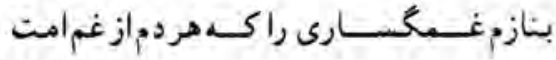

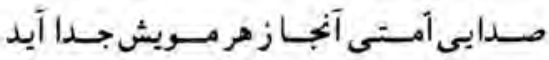

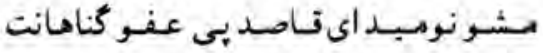

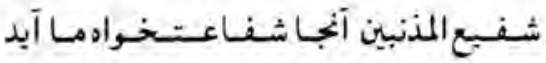

rE 


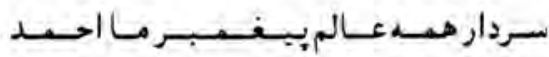

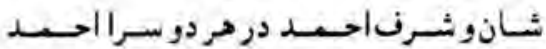

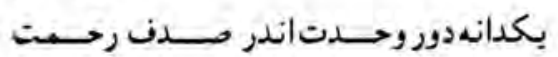

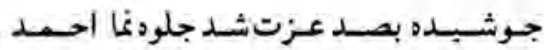

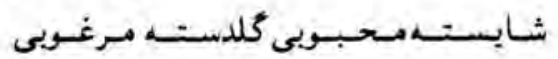

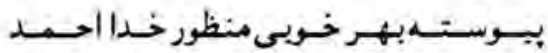

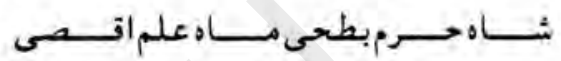

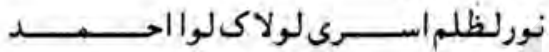

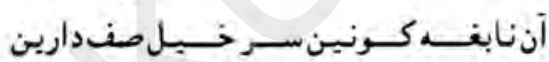

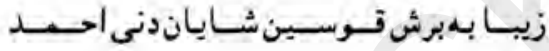

$$
\text { در هردو جـــان رِهبر بركـونو مكانسرور }
$$

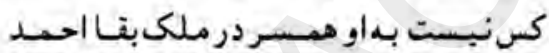

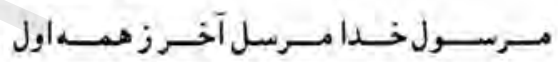

وزجـله جـهبان افـضل صـدر الكبـرا احسـد

جونكـــبـهدر آندرغـاهرو كـردهخليل الله

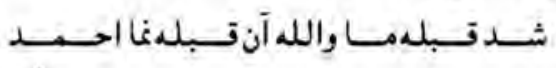

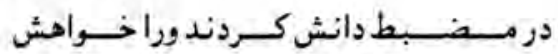

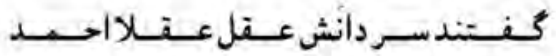




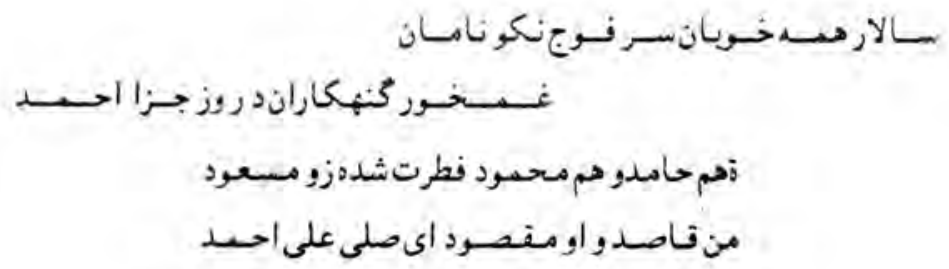




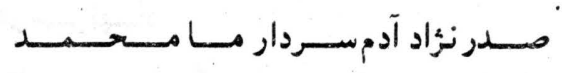

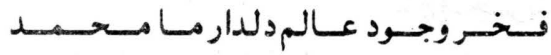

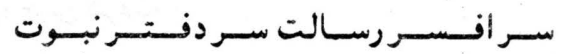

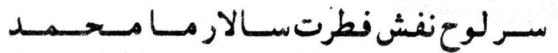

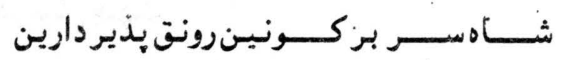

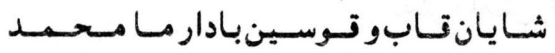

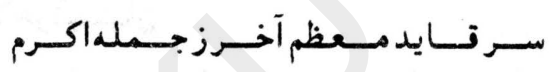

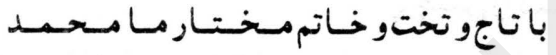

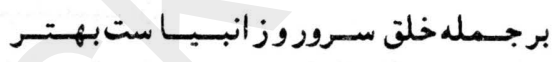

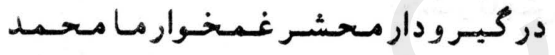

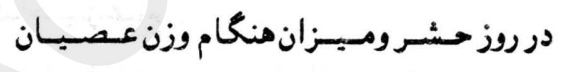

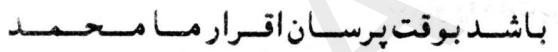

$$
\begin{aligned}
& \text { تـاصد زامتــان است سـر خبل عاصسيـان است }
\end{aligned}
$$

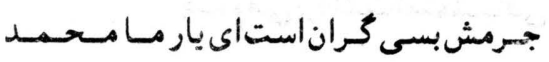




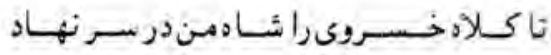

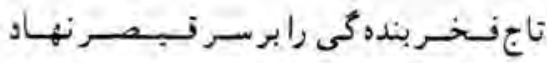

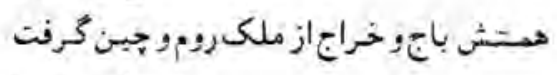

عظمتش بإىشـرف بر تخت اسكندر نهـاد

خسبرو ملكعـربتا سكمزد درشش جهبت

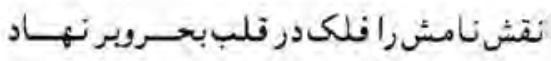

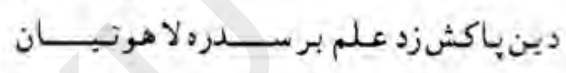

يرجمش رادست تـدر از عـرش بالاتر نهـاد

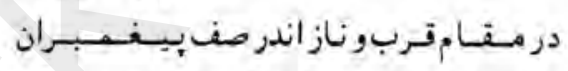

تخت وتاجش راز عـزت حـالقاكـبـرنهـاد

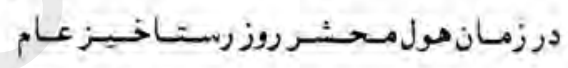

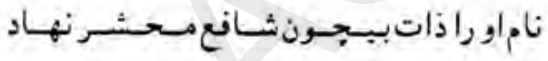

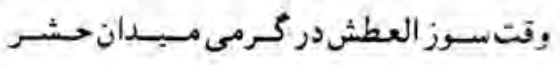

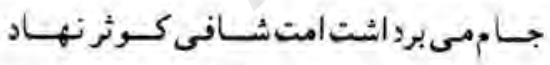

$$
\begin{aligned}
& \text { لب فرو بستاست قاصد بعد ازين ازممدع غير }
\end{aligned}
$$

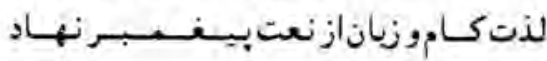




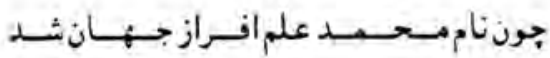

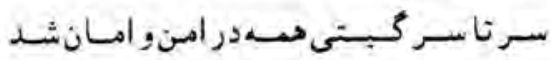

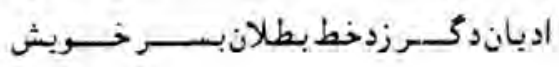

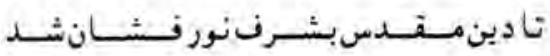

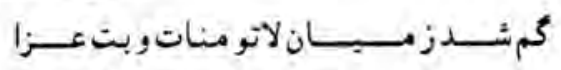

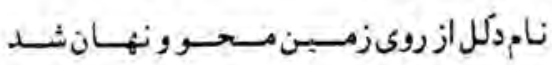

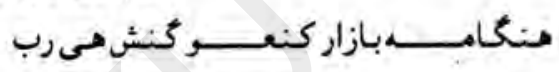

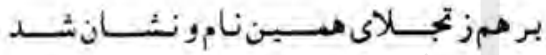

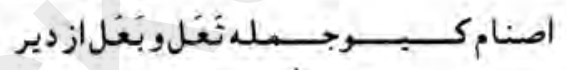

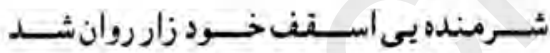

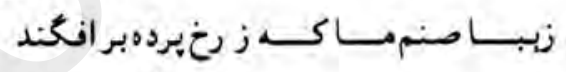

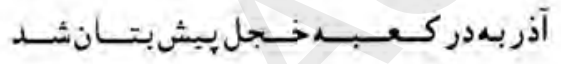

$$
\text { خسورشبـد جـان }
$$

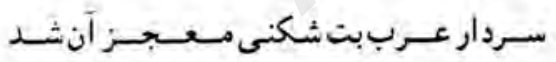

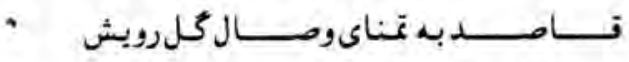

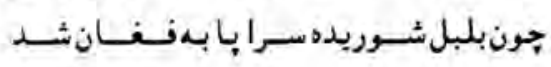




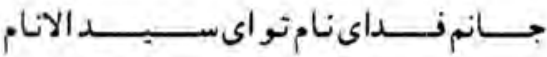

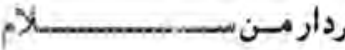

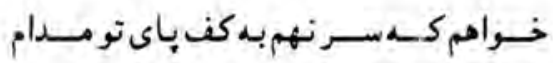

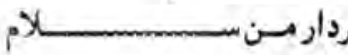

$$
\text { مـفـصـود هردوكسونتونىفسخـركـاينات }
$$

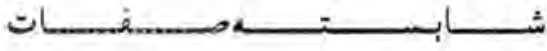

وصفثوظاهر است بـهرصـفــــلام

bx (بردار

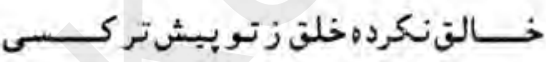

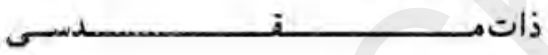

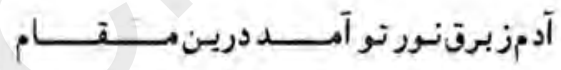

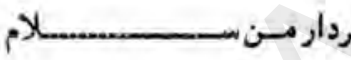

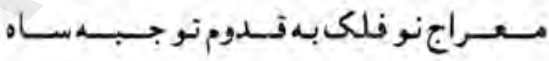

i بـا ش

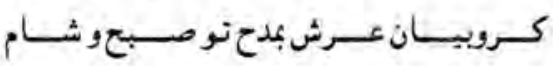

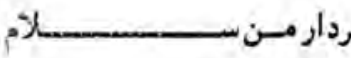

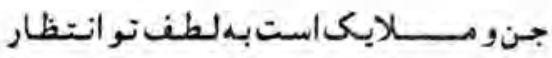

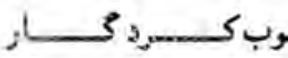




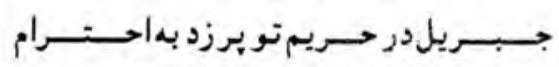

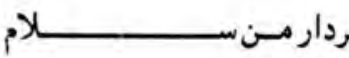

$$
\text { ازتسرب مسعسجـزات تومسـوسىشـد مكليم }
$$

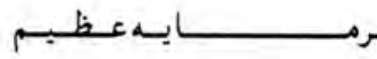

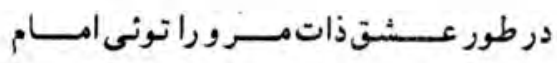

ble

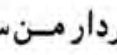

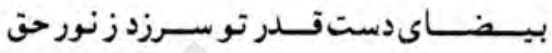
دوشـق ق

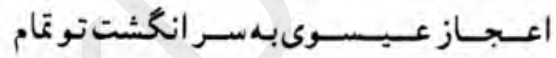

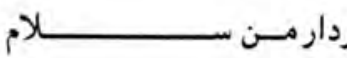

$$
\text { تـاصـدزصــقدلبهحسريمتشـهعـرب }
$$

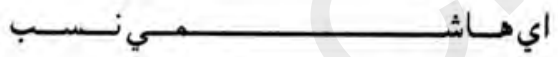

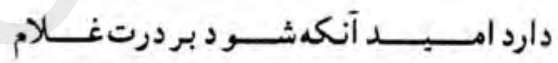

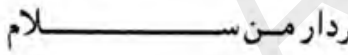




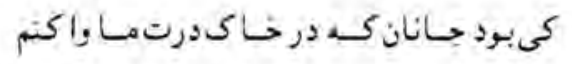

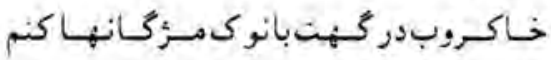

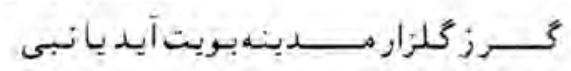

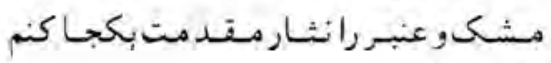

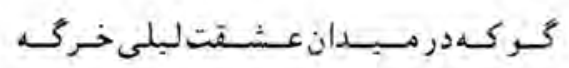

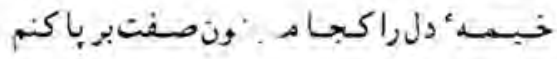

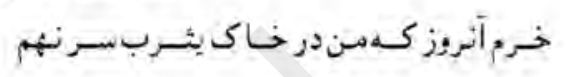

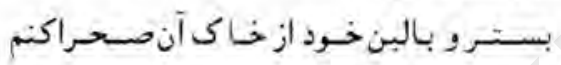

$$
\text { خوش همانساعت كمدر صحراى وصلتبكنرم }
$$

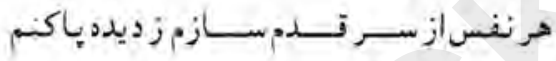

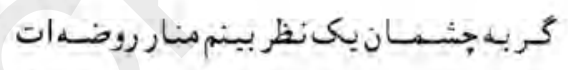

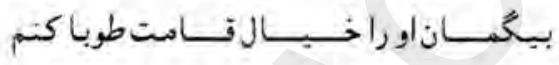

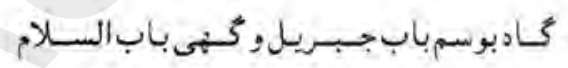

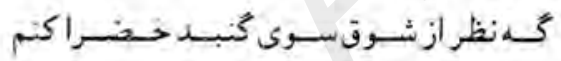

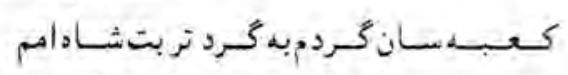

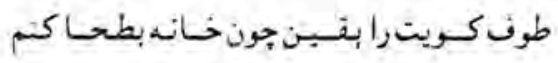

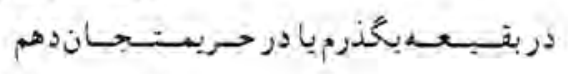

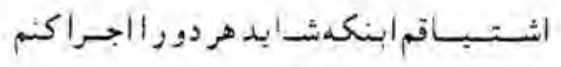

$$
\begin{aligned}
& \text { ملك جان بقروخت قاصد درغ ورسوداى دوست }
\end{aligned}
$$

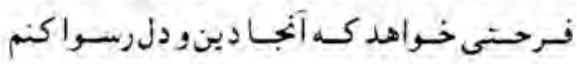

pr 


$$
\text { تا مـــــرف به كف بإى توشــد عـرض عظبم }
$$

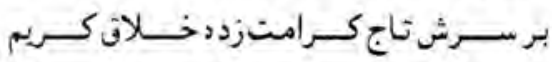

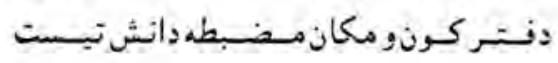

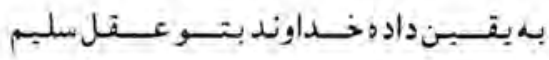

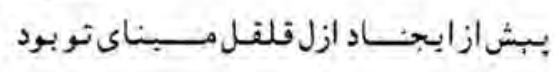

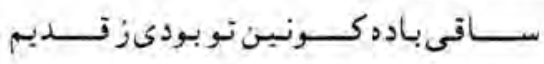

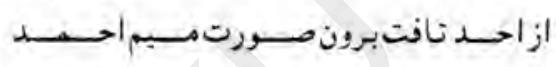

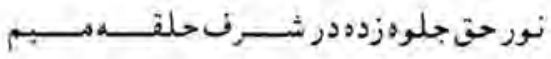

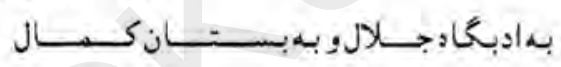

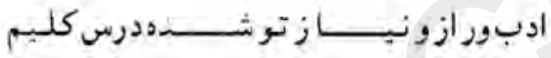

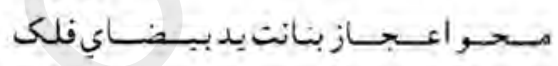

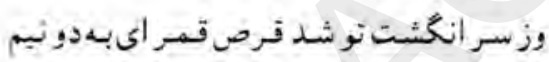

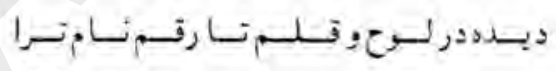

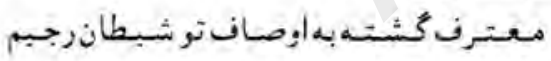

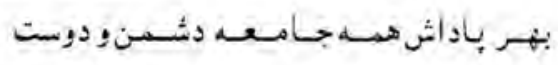

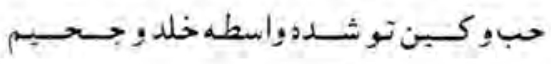

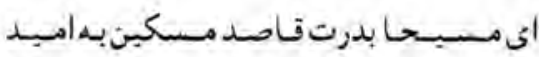

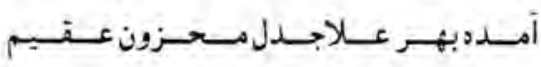




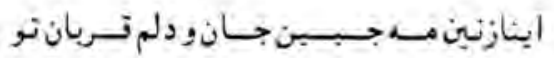

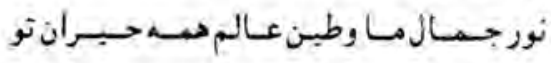

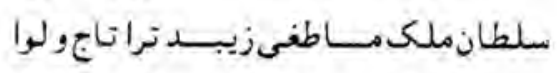

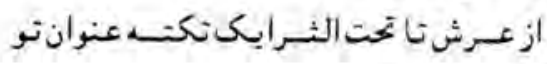

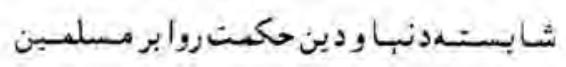

مـانده سليــانبانـكين سـرور خط فـرمانئو

$$
\text { شاهشته حسن جهان هبستى زلبخا ئزمان }
$$

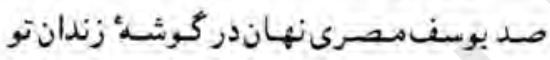

$$
\text { سـرخـبل خــبان عـرب روشنز توكـوي ادب }
$$

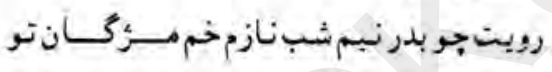

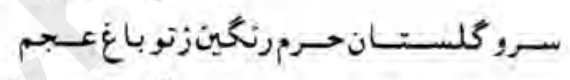

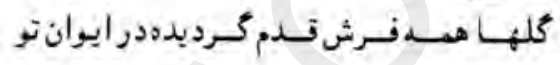

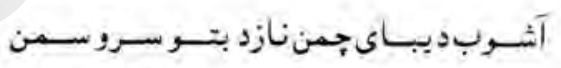

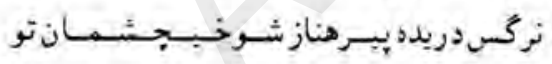

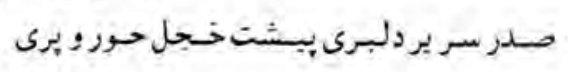

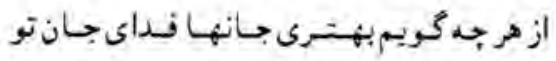

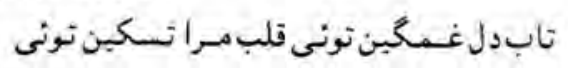

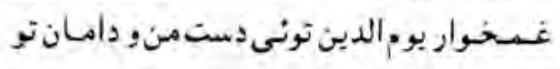

$$
\begin{aligned}
& \text { تاصدبه وصفتيا نبى كول است نادانوغبى بونى }
\end{aligned}
$$

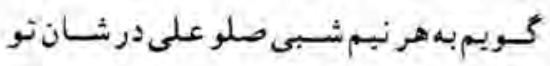

TE 


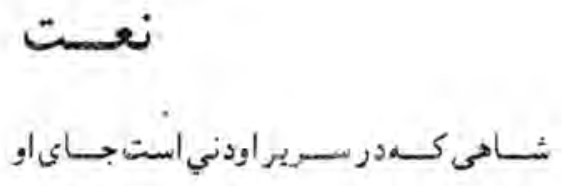

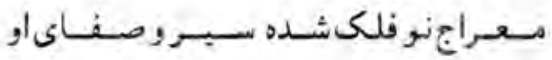

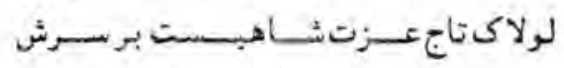

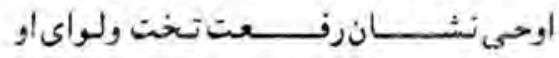

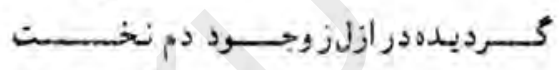

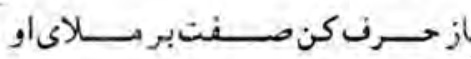

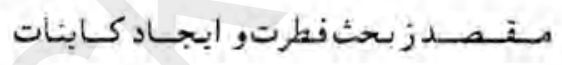

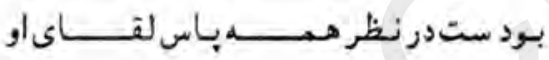

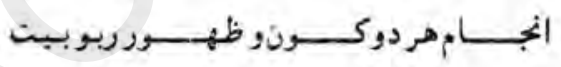

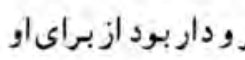

اين جسمانس

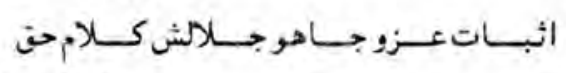

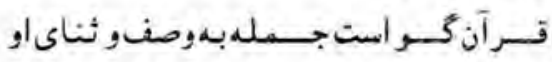

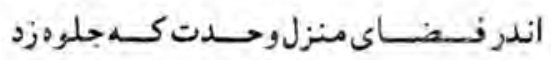

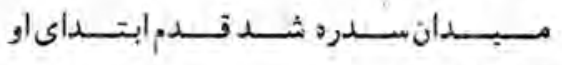

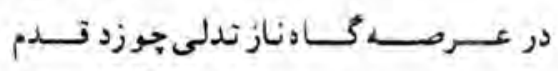

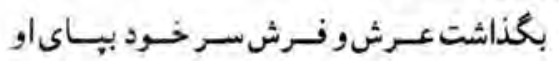




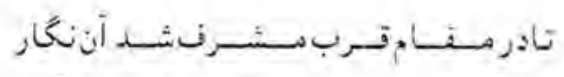

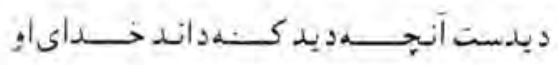

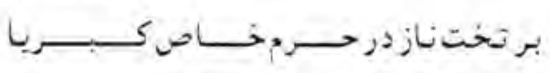

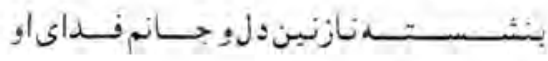

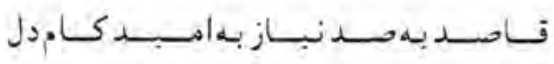

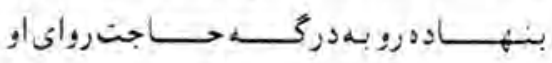




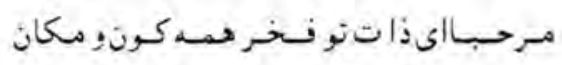

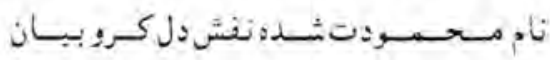

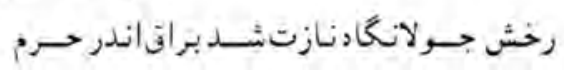

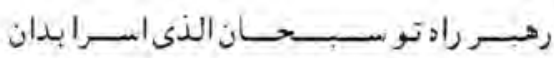

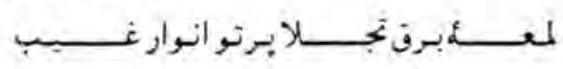

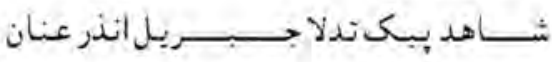

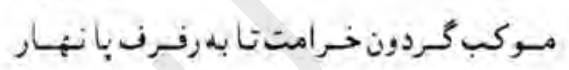

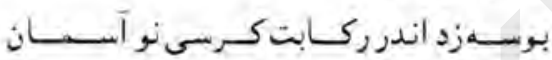

$$
\text { لى مع الله ياورت أيثـــــــــاركـابنات }
$$

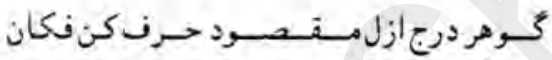

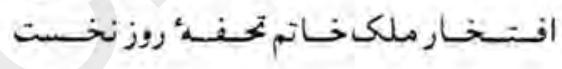

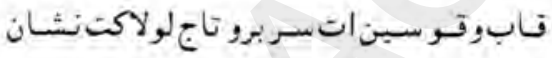

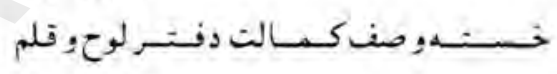

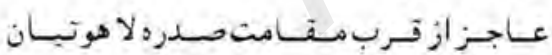

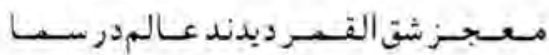

ابر رحسمت بر سـرت خـرويدهر جـا سـاببـان

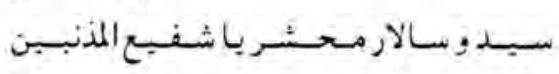

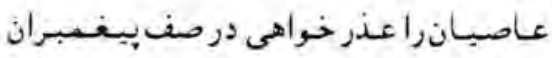




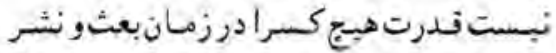

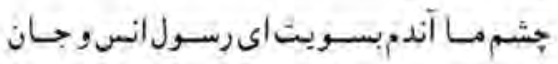

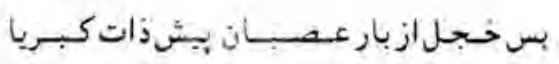

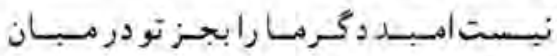

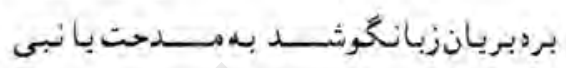

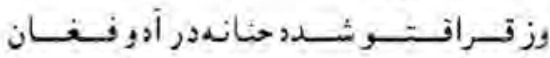

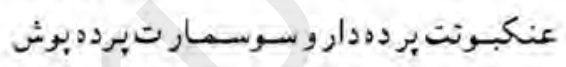

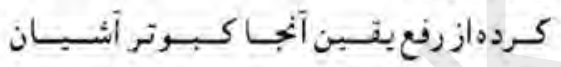

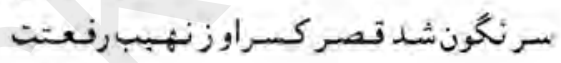

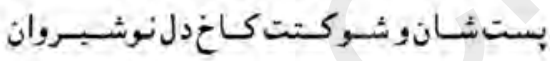

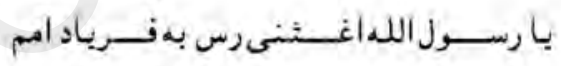

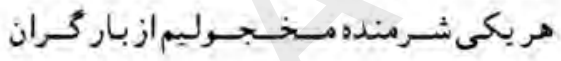

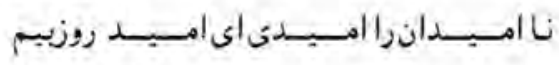

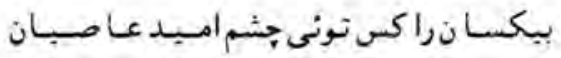

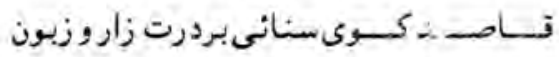

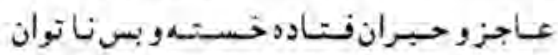




$$
\text { بارســول الله تونئىســــــوبرب العـالمبن }
$$

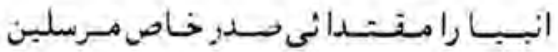

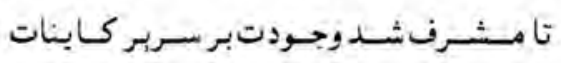

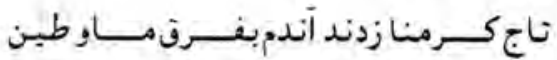

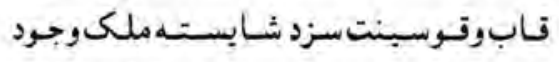

خلوت لولاكى همىزيبـدترا ايى مـهـهـــــين

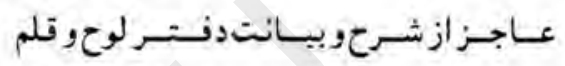

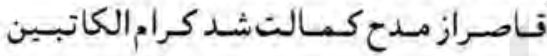

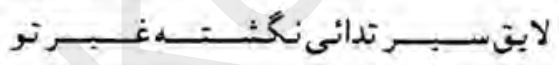

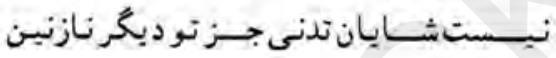

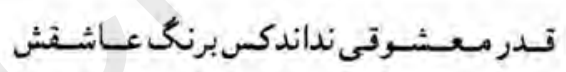

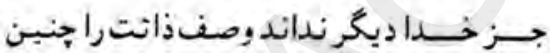

$$
\text { درحريمت هركه، يز شـدرسد كارش بهكام }
$$

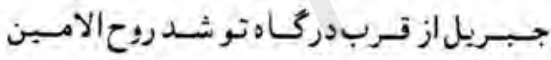

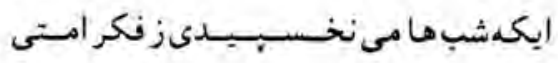

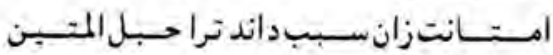

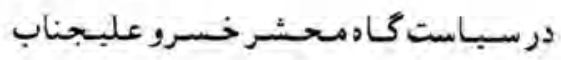

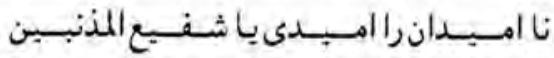




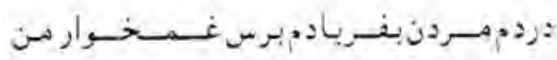

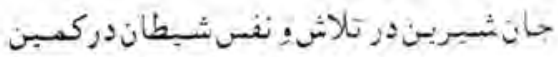

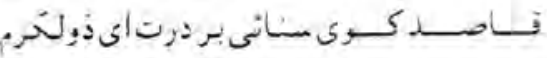

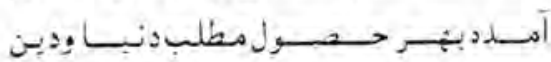




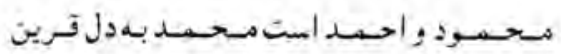

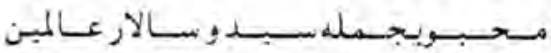

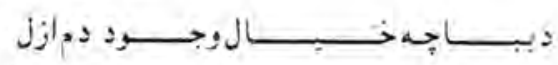

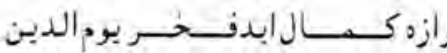

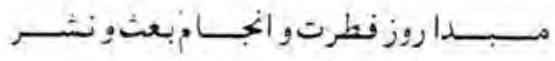

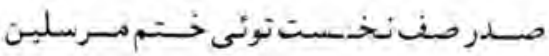

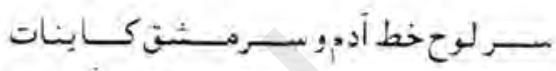

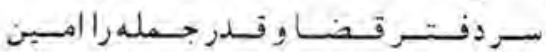

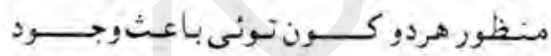

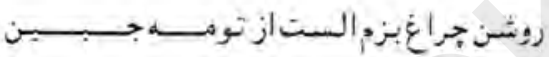

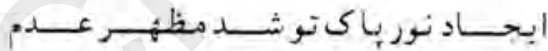

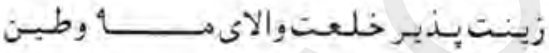

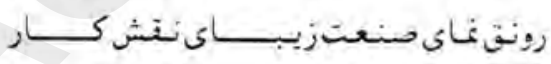

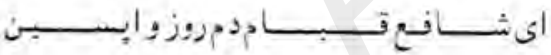

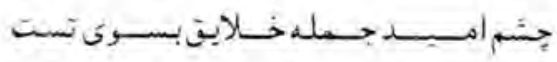

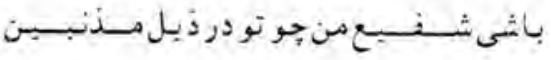

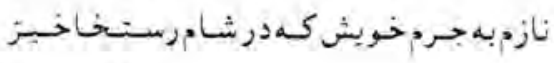

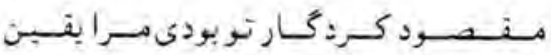

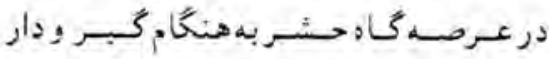

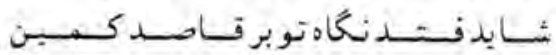




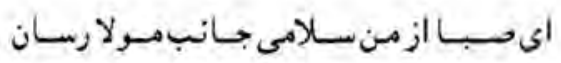

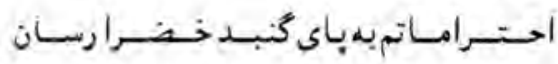

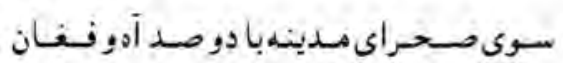

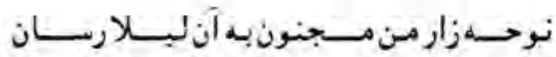

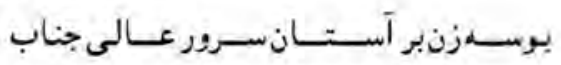

هر قــدمدركسوى اوسـر رابجـاى بيا رسبـان

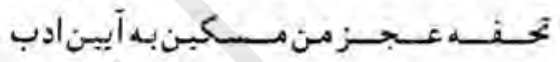

داعـلا رســان

ia

$$
\begin{aligned}
& \text { درحسريمبروض }
\end{aligned}
$$

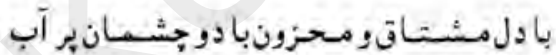

عـرض حسالم را بشيـاه يثرب وبطحسا ريسان

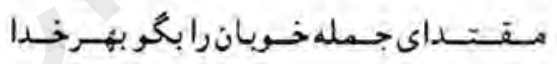

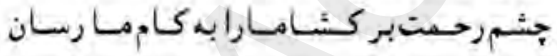

كـو كم دوبازار عشـقت يوسف مـصر جهـان

جونزليـخـا من خــريدارميبـاممرا رســان

العطش گـــــان منم دردستشـوفت هرطرن

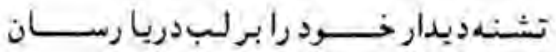

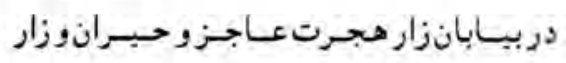

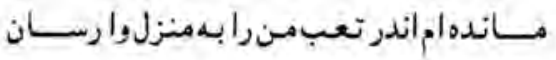




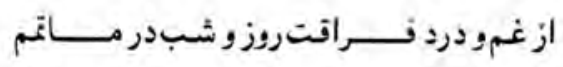

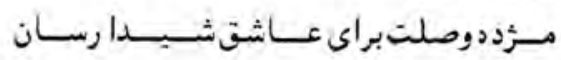

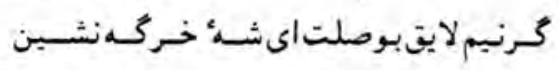

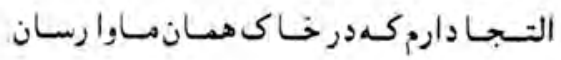

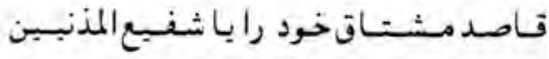

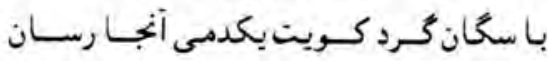




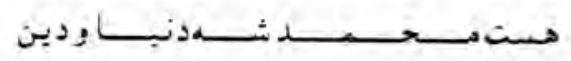

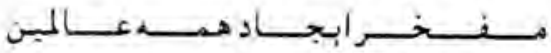

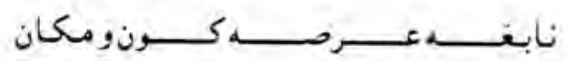

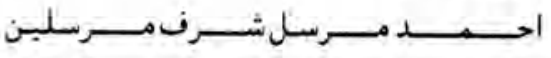

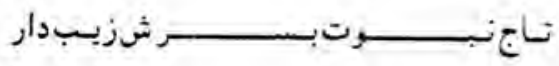

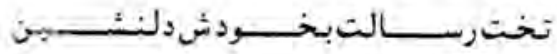

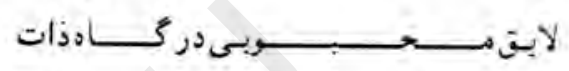

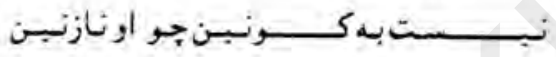

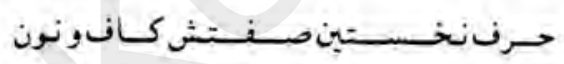

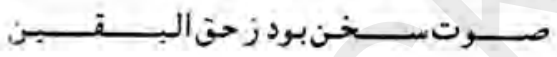

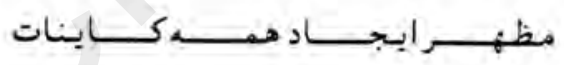

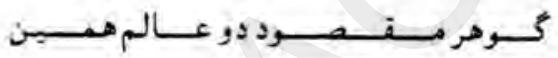

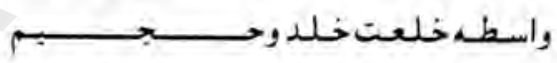

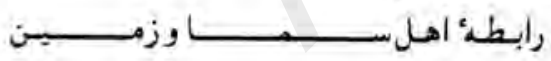

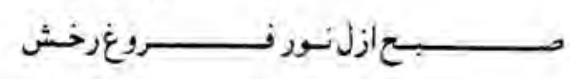

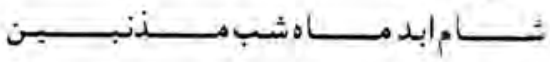

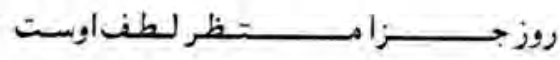

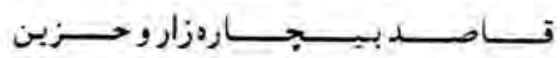


منز هجرت يامسحسد ازدل وجـان سـوختم

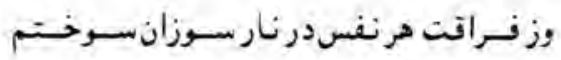

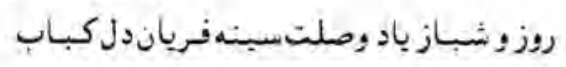

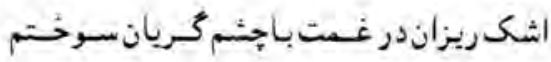

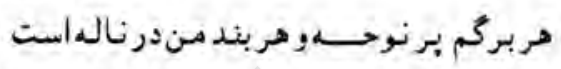

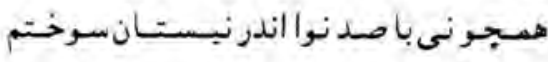

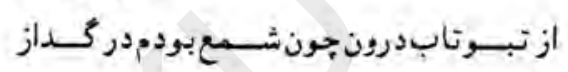

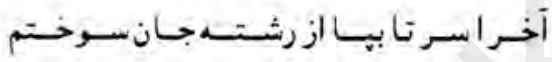

$$
\text { جـانمنيا آتش هجسر توازبس خــوكـرفت }
$$

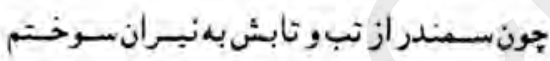

$$
\text { كاش مبـديدمجـــالترابخـواب خهود بسىى }
$$

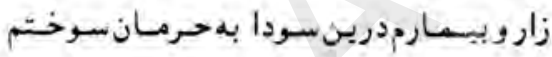

سـالهـا در مـصـر غمبر من نكردى يكنظر

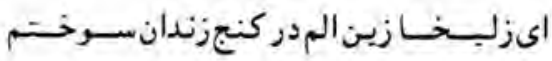

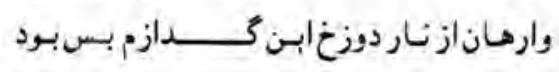

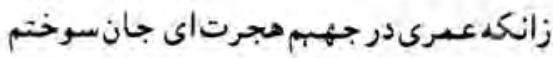

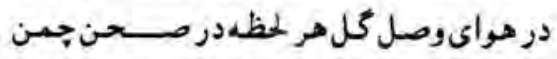

$$
\begin{aligned}
& \text { تـاصـدمبلبل صـفتدر آهو افـفــانسـوختم }
\end{aligned}
$$




\section{معروضه بحضور مبارك فخر دو جهان}

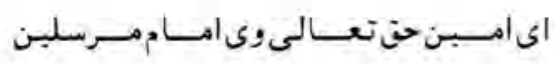

مـنـــــداى جـمله عـالمر رجسمت اللعـالمبين

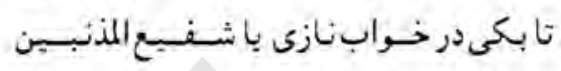

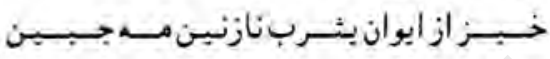

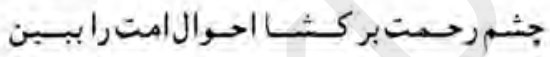

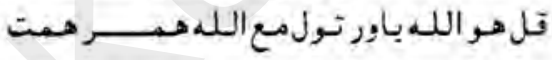

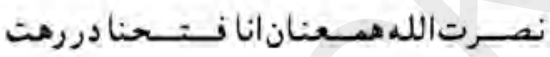

$$
\text { جـــم امسبـددو عـالم مـانده سـوى دركـهت }
$$

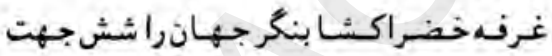

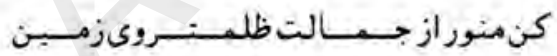

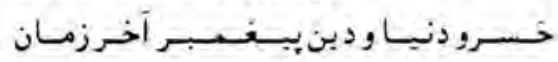

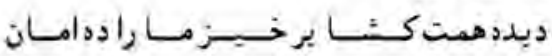

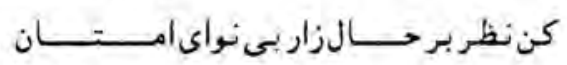

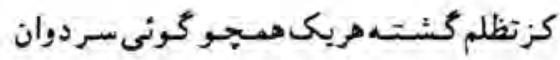

$$
\text { نيستمـا را جز نوكس غمخسوار روزوايسين }
$$




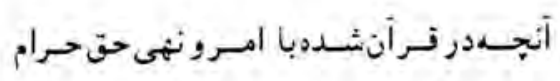

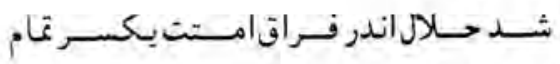

كذبو غيبت كُنته ورد اندرزبان خاصوعـام

خمـرو ميسسرشـد رواج مسحفل اوشـانمـدام

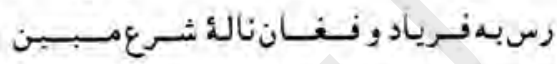

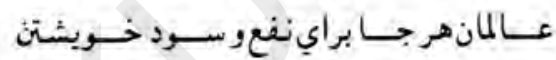

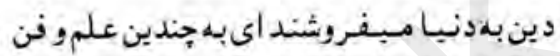

$$
\text { وعظوريند شـان غـرض آثــوبـنكر مـردوزن }
$$

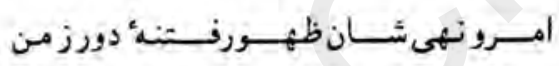

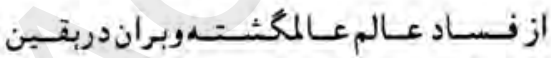

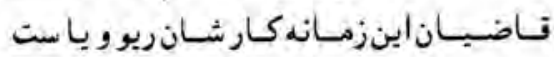

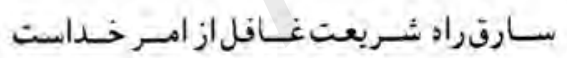

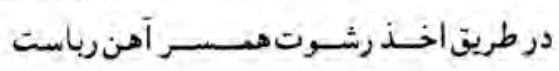

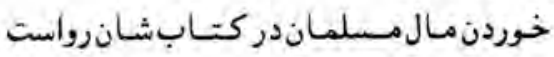

$$
\text { حسرت تخت قضا افسوس ازين مسند نشين }
$$


صـونـيـانصـاف مـا لاف مستلفانى زتند

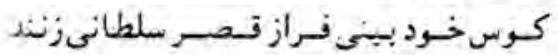

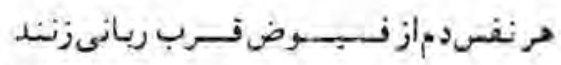

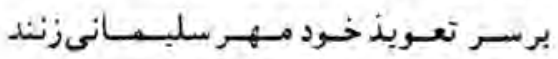

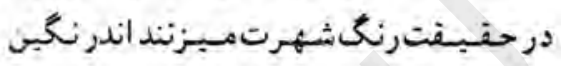

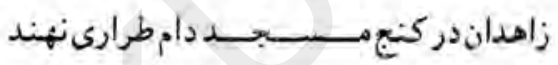

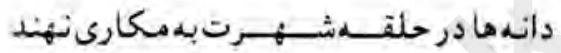

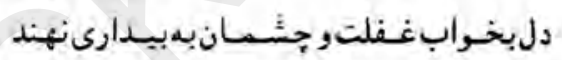

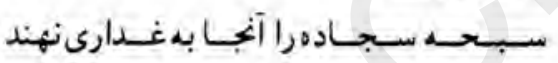

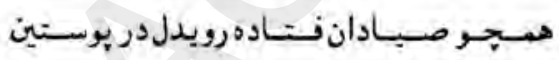

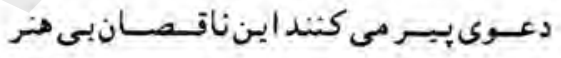

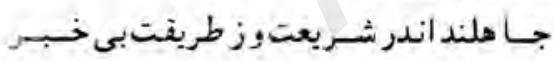

$$
\text { شــز خرجو مـصرفاوشـان مـريداندربهدر }
$$

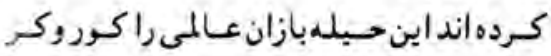

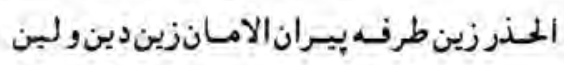




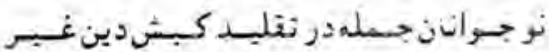

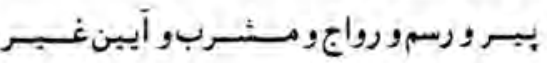

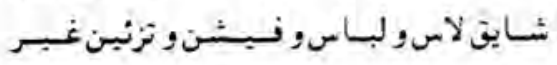

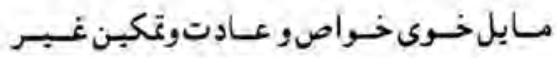

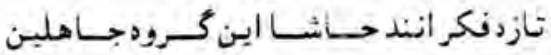

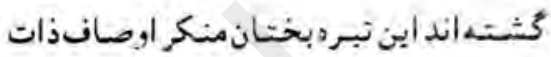

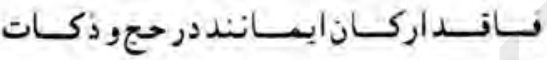

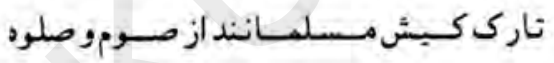

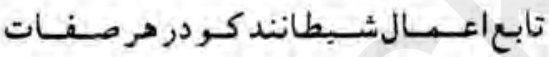

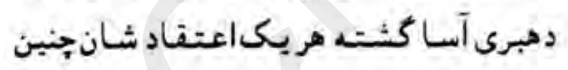

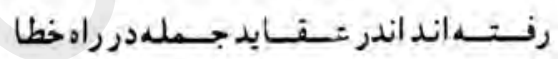

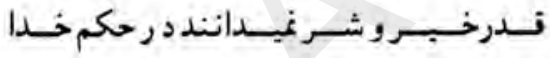

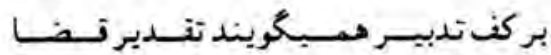

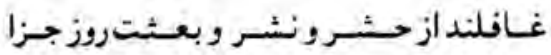

$$
\text { كُشته حيرانشرقو غربازخبر ودار مشـركين }
$$




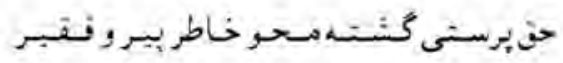
تن يرنستى شــد خــواص و عـادت برناو بيبـر

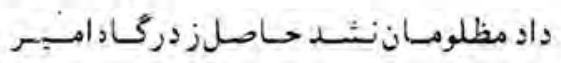

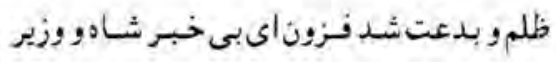

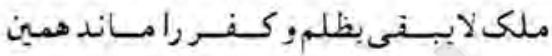

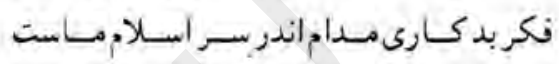

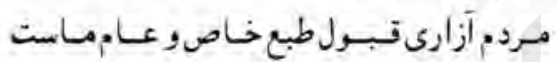

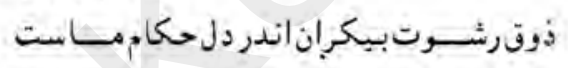

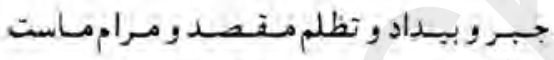

$$
\begin{aligned}
& \text { هرنفس ســوداي مـاشـــنفعروســود آنو ابن }
\end{aligned}
$$

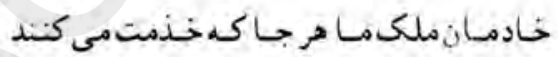

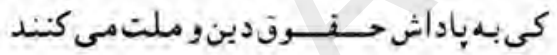

$$
\text { جـان نثـاريهــا بنام مــال ودولتمى كنتد }
$$

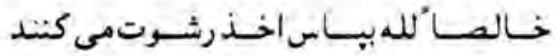

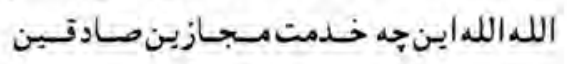




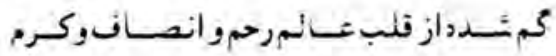

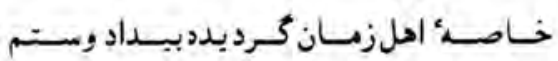

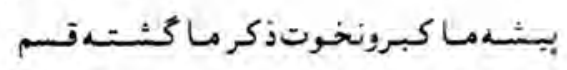

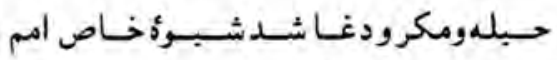

نبستاوصـاف مسلمانى بكي راهـفربن

رسم الفتنيستبـاقى در خـيـال شـيخوشـاب

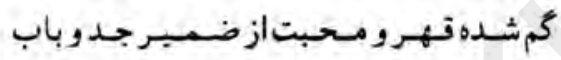

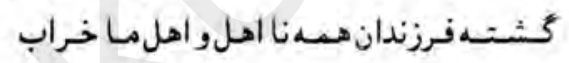

نى يدر را ازيسر سـودى نى خبر وني صسواب

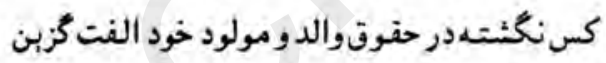

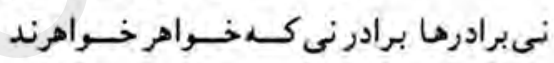

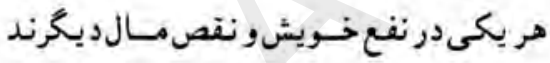

$$
\text { هركســا بنسىزنان مبرشـوهرانراشـوهر اند }
$$

مـادر ودخـتـر كنون بر همـديخر جون اندر اند

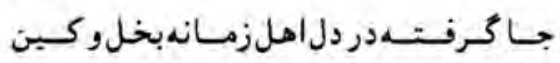




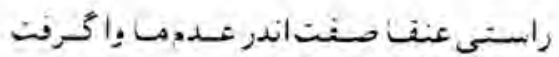

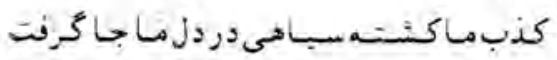

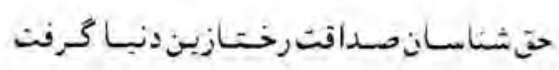

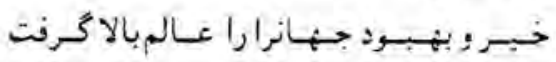

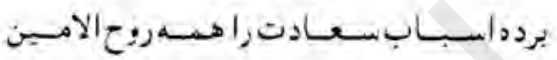

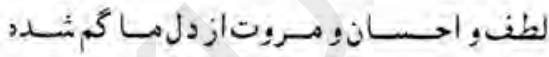

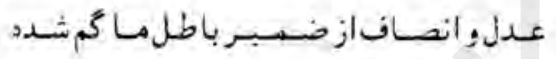

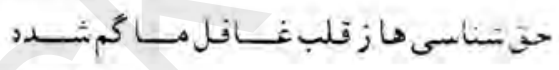

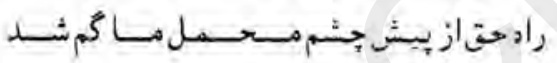

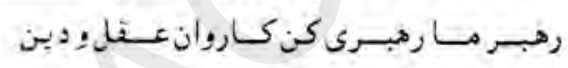

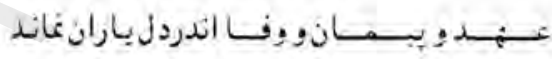

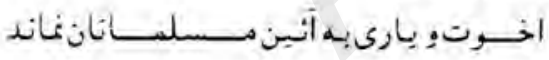

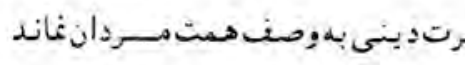

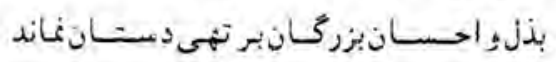

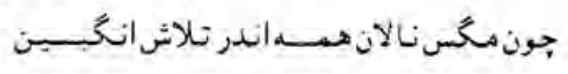




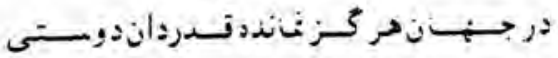

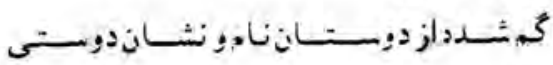

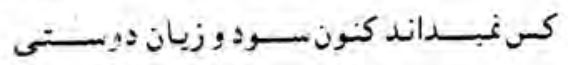

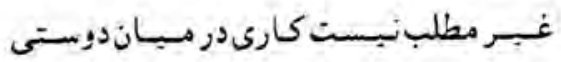

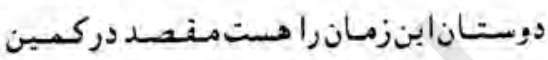

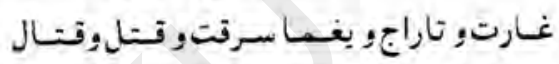

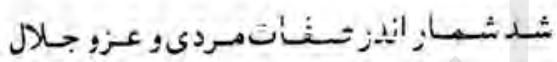

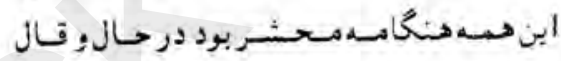

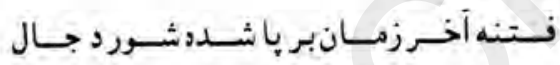

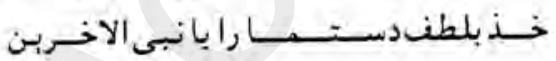

$$
\begin{aligned}
& \text { هـنى فـرمـا يبيـامبــرزانكهروز همتاست }
\end{aligned}
$$

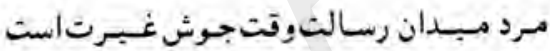

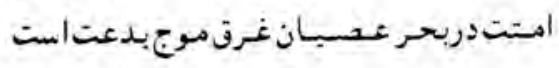

جمله كى سرشارو بيخود مست جامغنقلت است

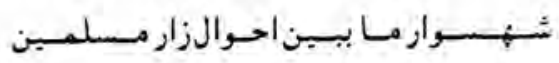




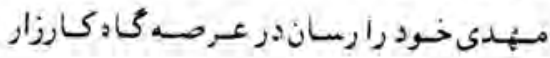

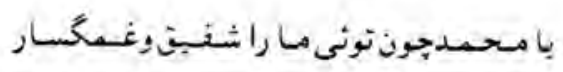

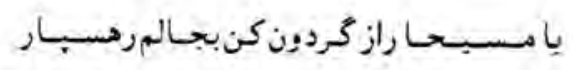

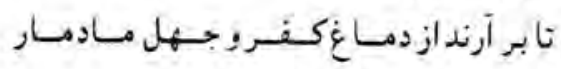

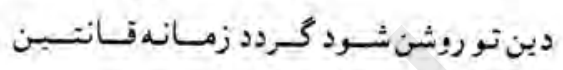

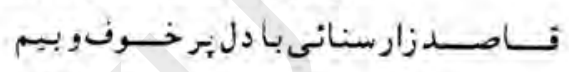

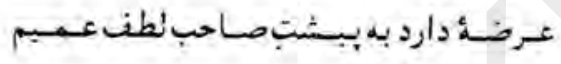

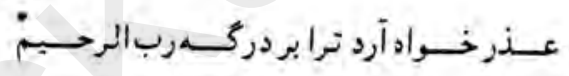

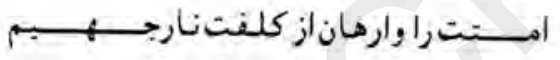

$$
\text { دستمبـا ودامثتمــارا توثيى حسبل المتــين }
$$




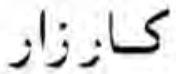

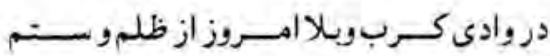

سر اهل ببت مصطفى با خاكى وخون يكجا بهم

$$
\text { كسنيست ثا احسوالمـا كـويد به آنشـاهامم }
$$

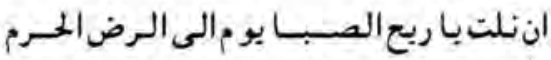

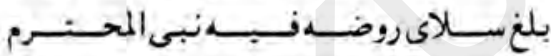

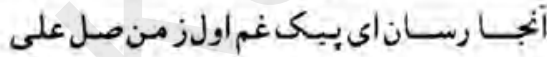

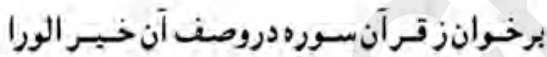

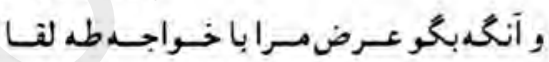

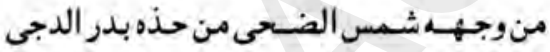

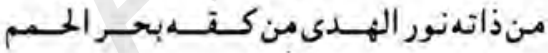

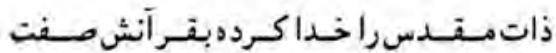

وزكبش و أيَّش جهـانديده سـراسر منفعت

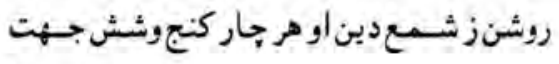

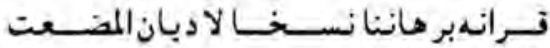

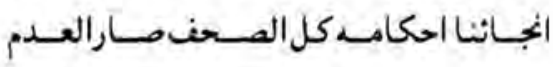




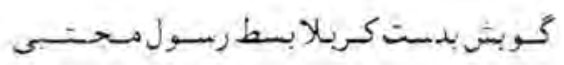

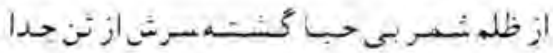

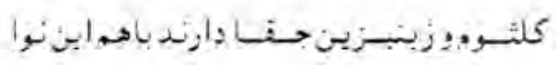

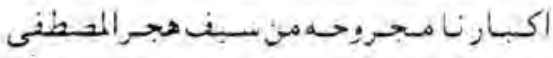

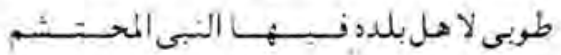

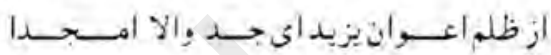

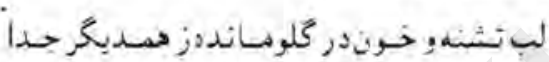

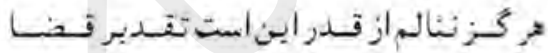

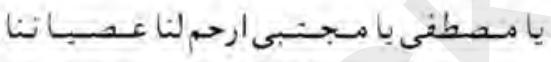

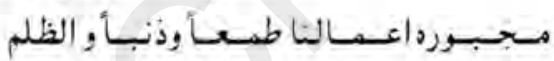

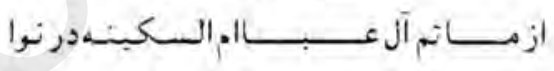

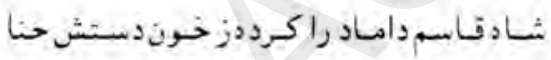

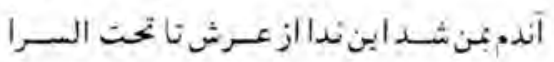

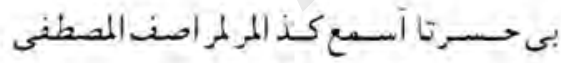

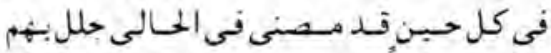

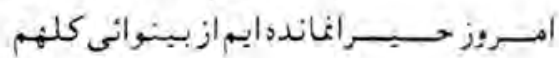

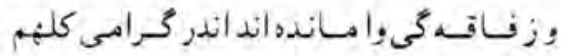




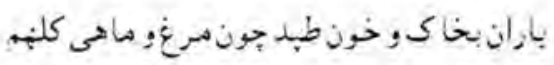

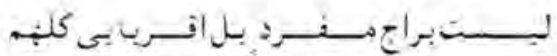

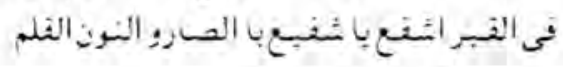

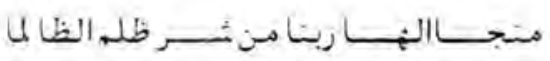

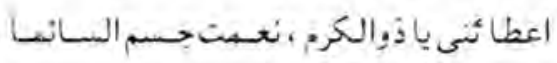

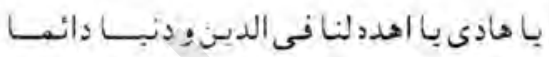

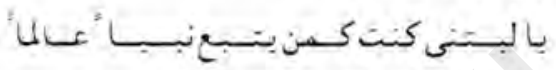

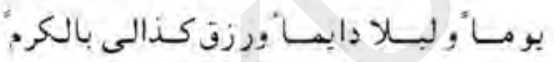

فخر وجسود مـ رطين حسدركـرودمرسلين

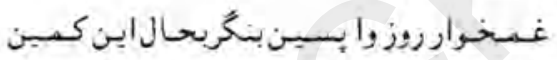

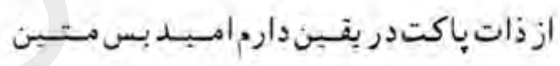

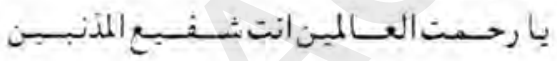

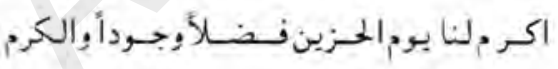

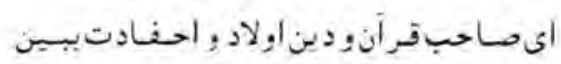

كز وست ظلم الظألمين بامال غم كُشت احسبر

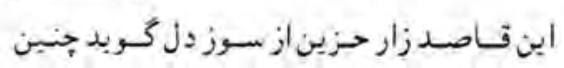

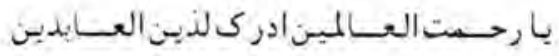

$$
\text { مسحبـوس ايدى الظالمبن فـبـالموكب رالمزدهم }
$$




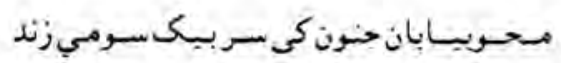

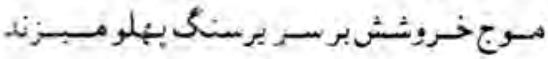

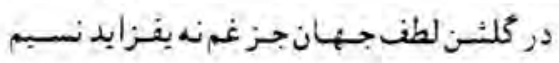

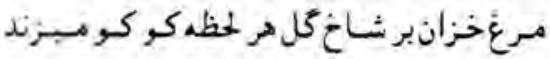

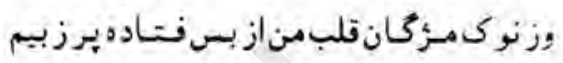

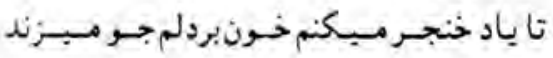

$$
\text { جان وتنم جـوشدز غم مهرش نشد از سر برون }
$$

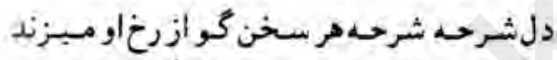

$$
\text { بردور مـادعـارضتكـاكل بهـردم جـبم مـار }
$$

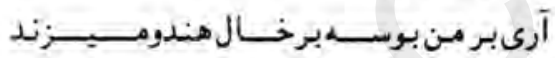

$$
\text { بك حلفه جعد مـوي تو خنديده بر مسشك خاتن }
$$

صـدطعندزلف عنبــرت بر ناف آهر مسبـزند

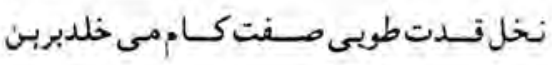

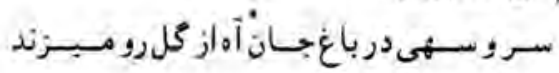

$$
\text { مـأر رخت اندر حسرمبذرلفـاى رحسمتاست }
$$

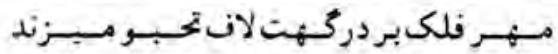

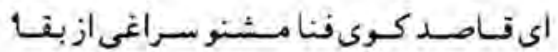

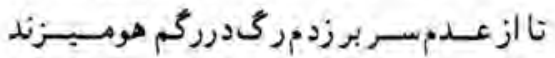




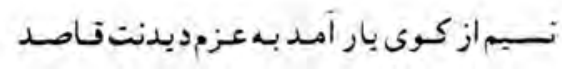

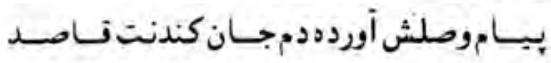

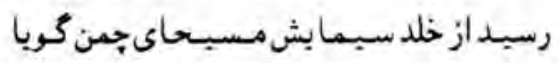

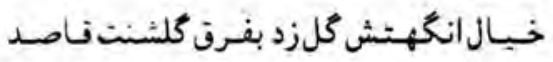

$$
\text { بهار عمر مشتـاقان عبث بإمال حسرت دان }
$$

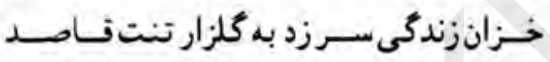

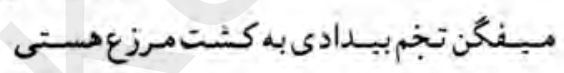

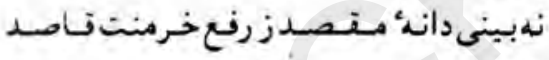

$$
\text { جهان سوداي ناكامى استو عقبا كلفتاعمال }
$$

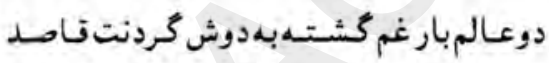

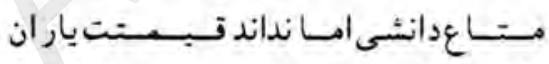

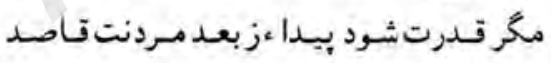




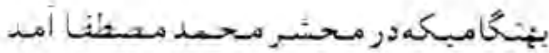

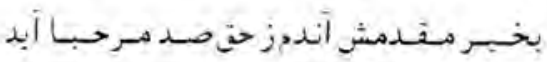

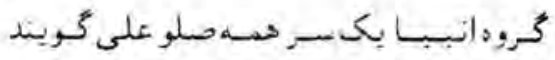

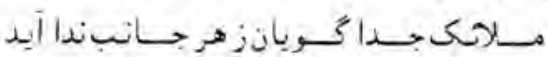

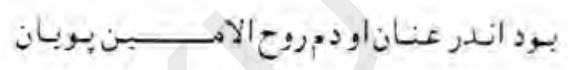

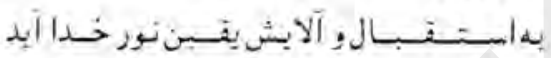

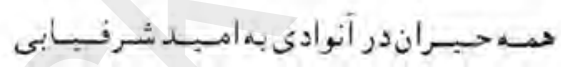

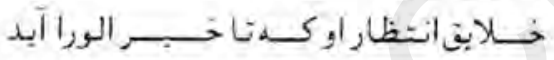




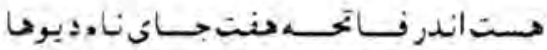

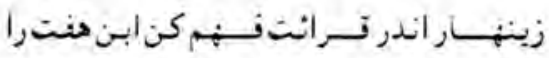

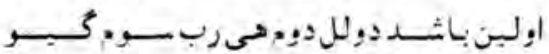

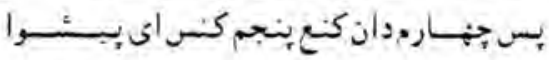

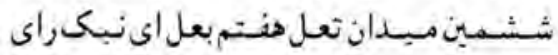

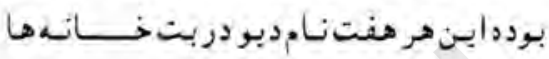

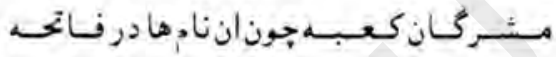

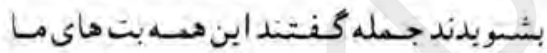

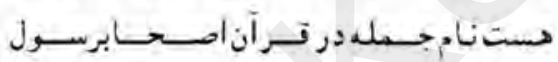

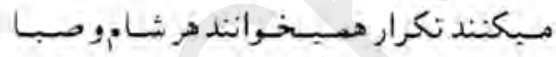

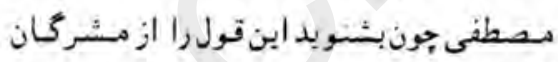

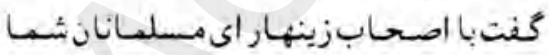

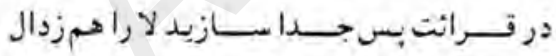

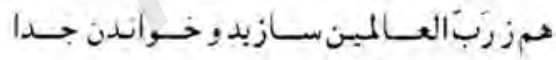

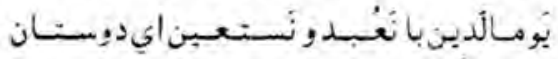

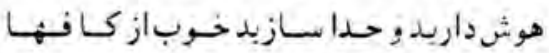

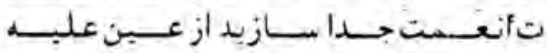

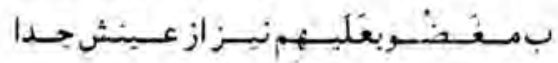




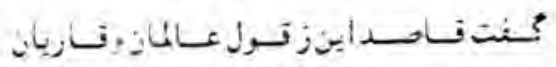 \\ كالمان}

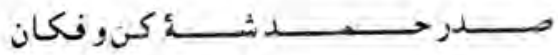

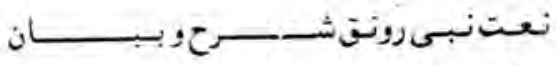

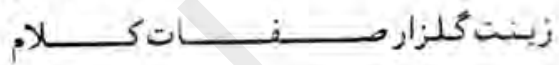

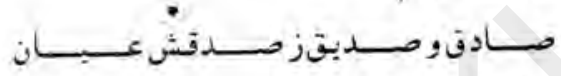

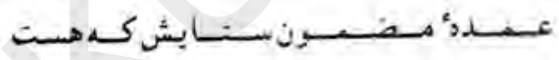

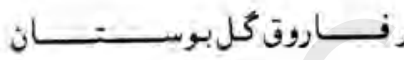

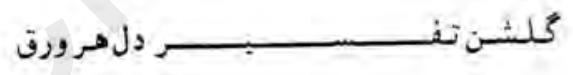

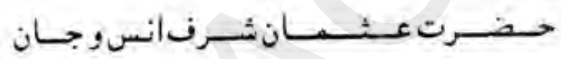

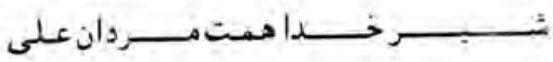

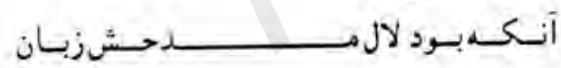

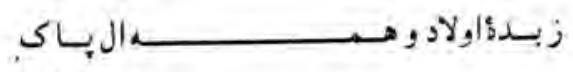

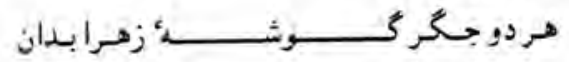

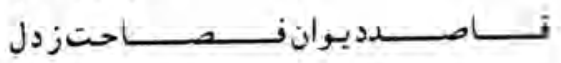

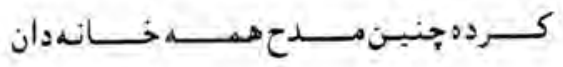




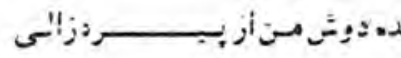

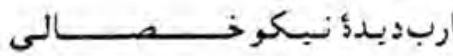

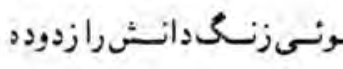

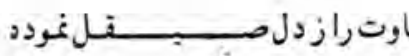

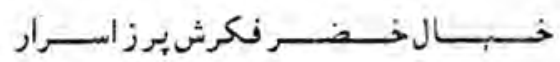

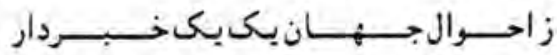

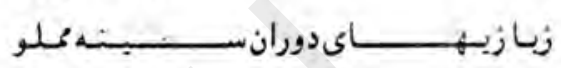

ترناز ارسطرو

ريسودن نـرده

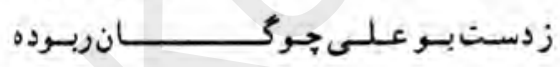

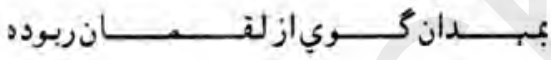

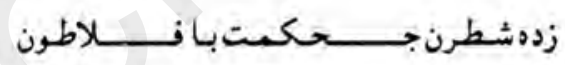

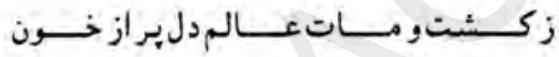

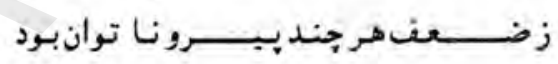

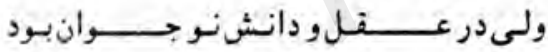

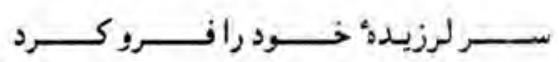

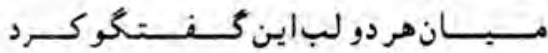

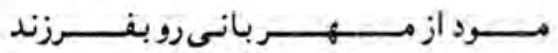

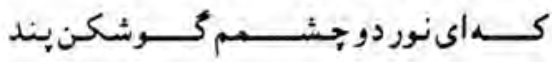




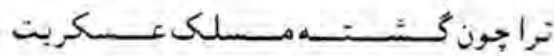

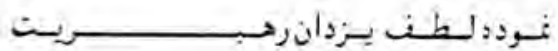

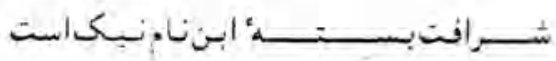

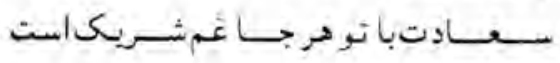

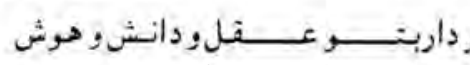

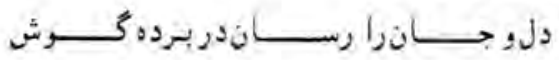

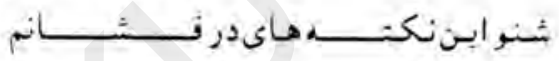

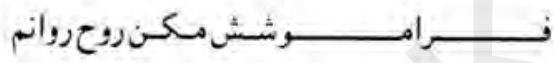

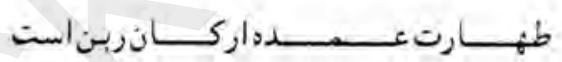

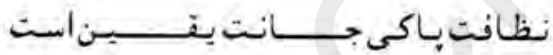

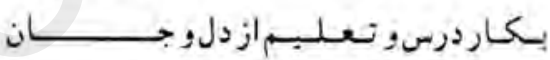

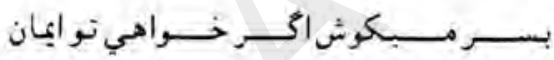

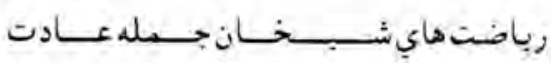

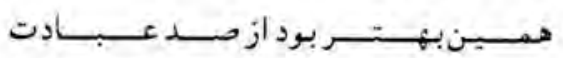

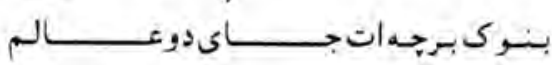

دمتسن

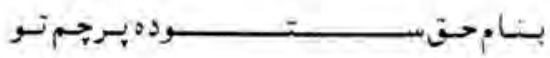

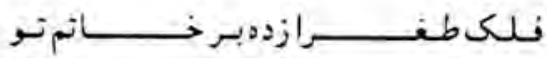




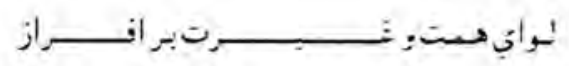

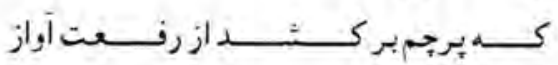

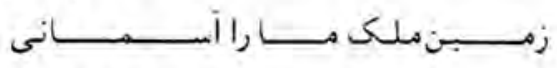

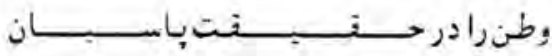

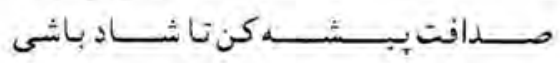

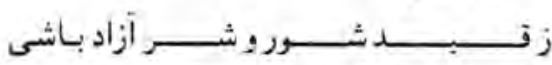

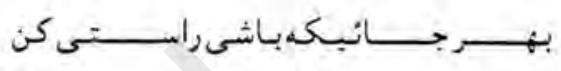

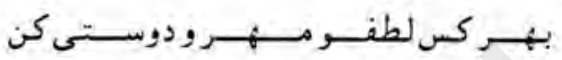

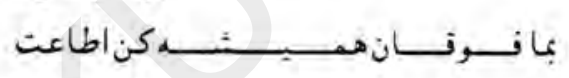

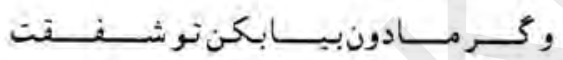

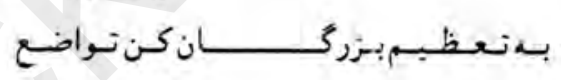

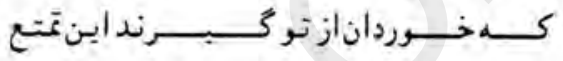

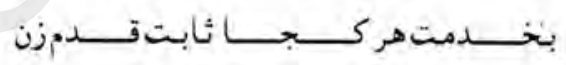

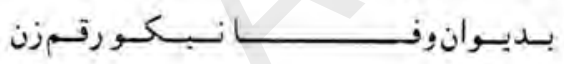

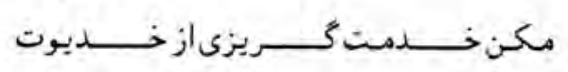

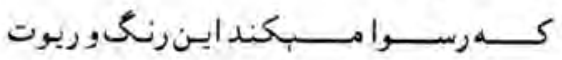

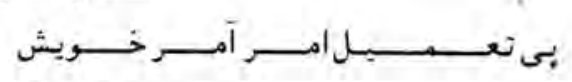

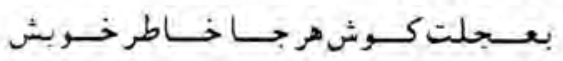




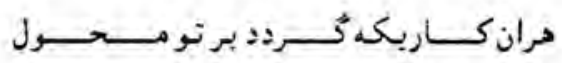

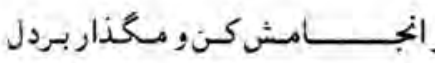

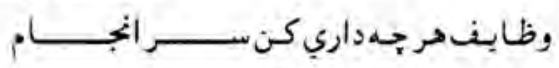

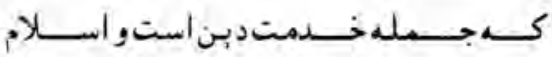

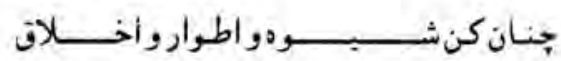

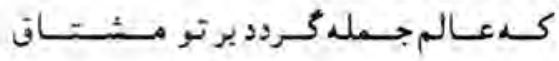

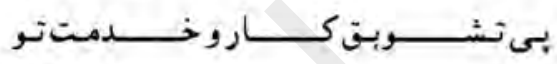

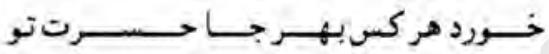

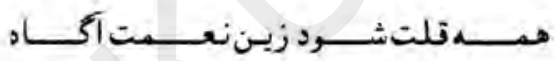

وى اينراه

وقدل

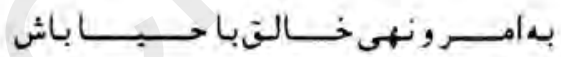

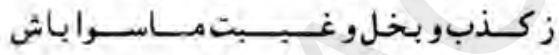

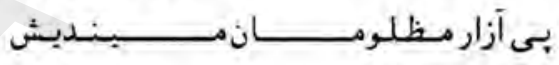

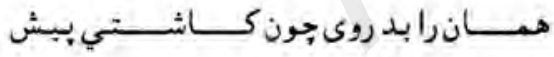

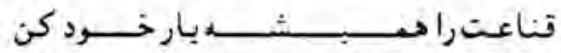

تــوكسل رونـق بـازارخ

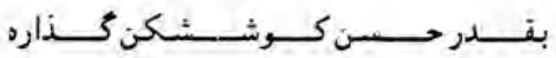

كن نطاره

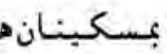




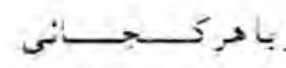

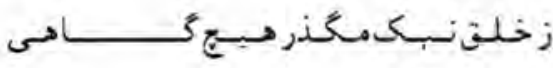

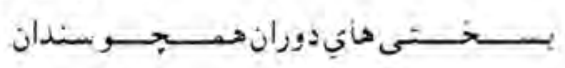

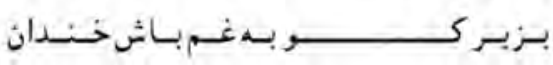

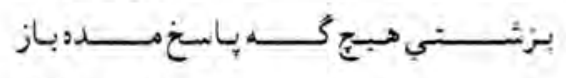

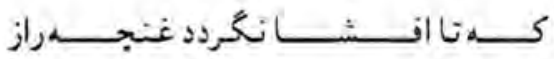

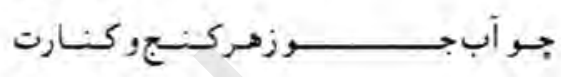

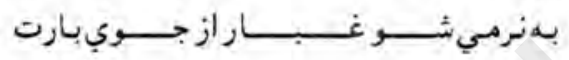

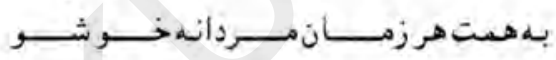

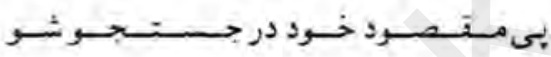

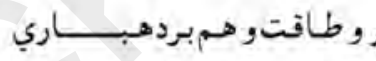

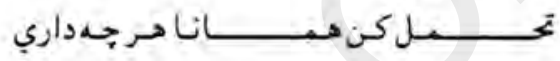

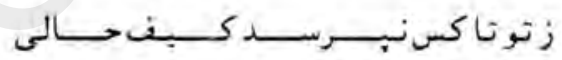

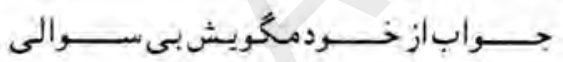

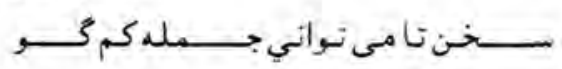

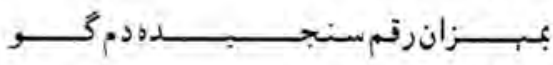

زيسـرگ

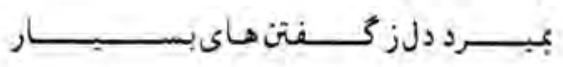




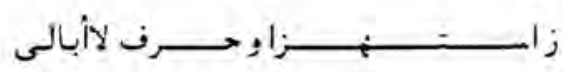

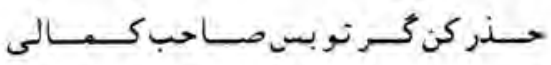

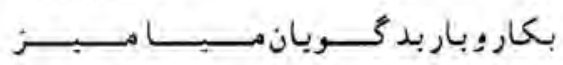

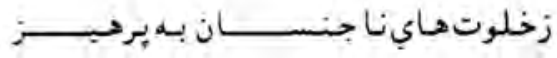

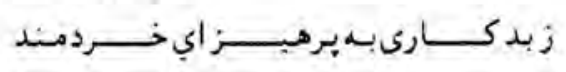

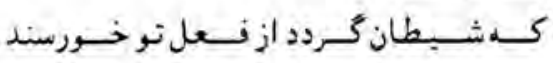

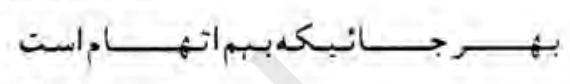

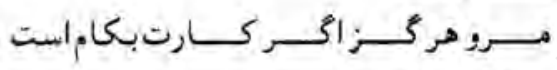

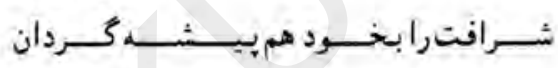

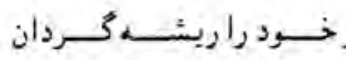

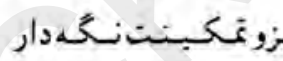

; ن

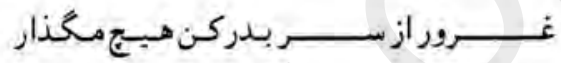

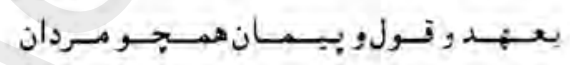

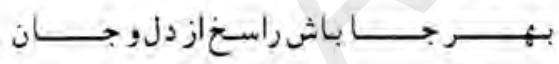

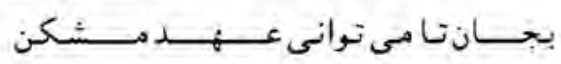

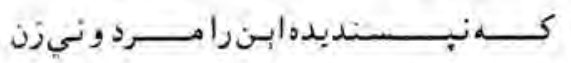

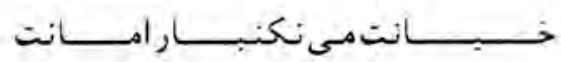

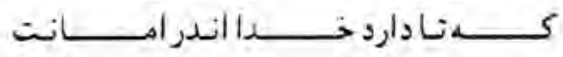




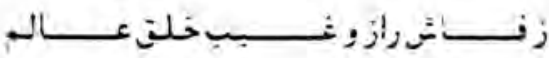

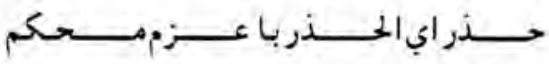

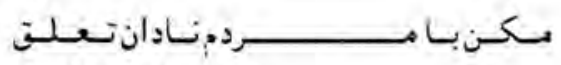

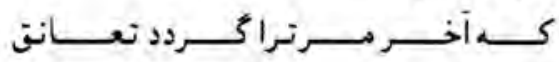

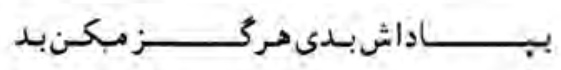

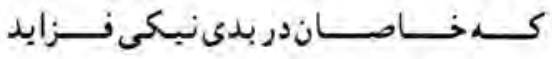

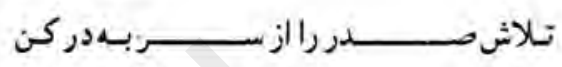

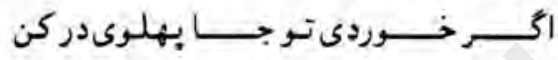

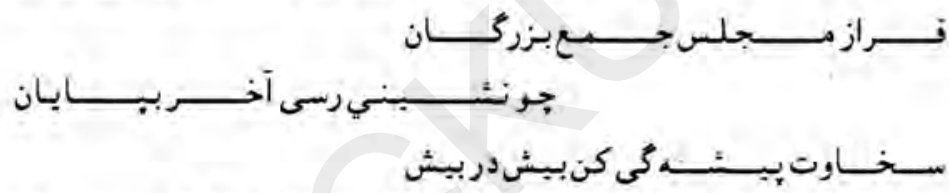

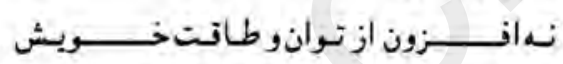

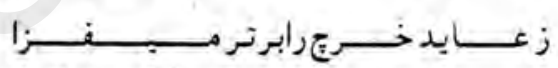

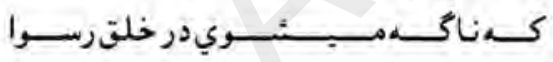

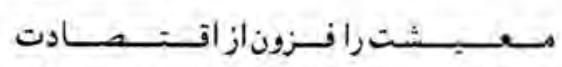

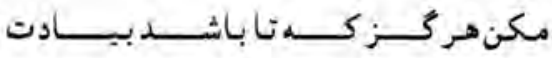

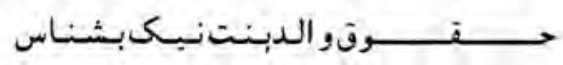

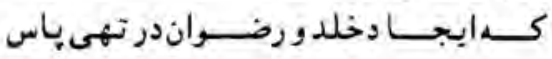

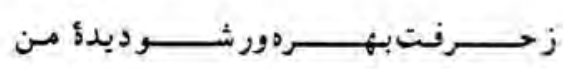

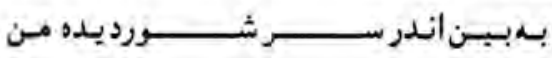




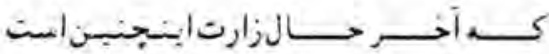

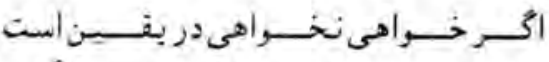

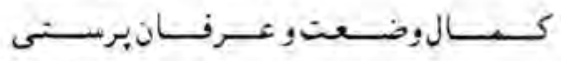

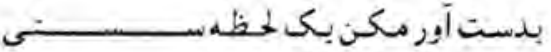

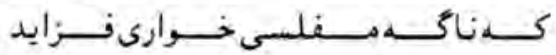

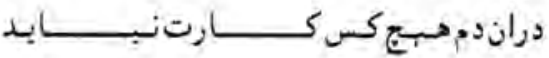

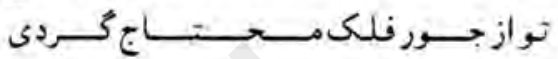

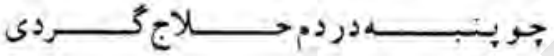

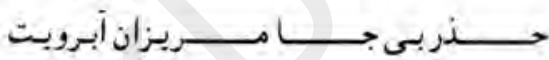

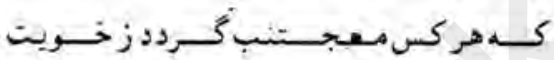

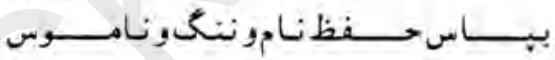

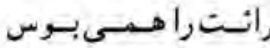

د.

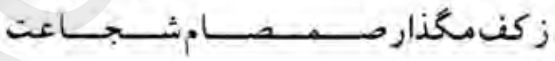

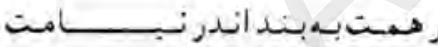

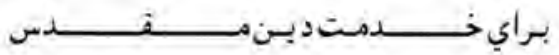

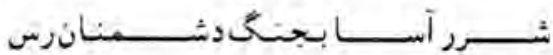

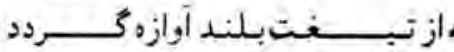

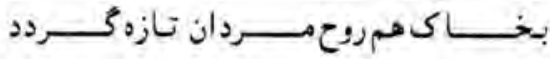

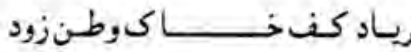

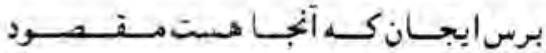

v. 


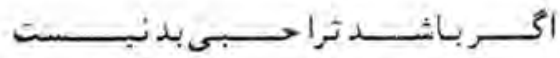

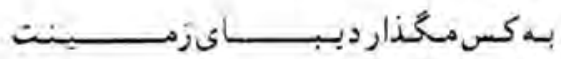

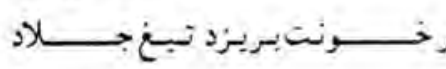

كا اجســـداد $>$ i لمد بروثتدش بـ

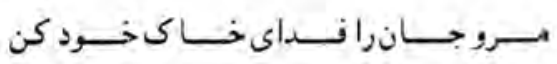

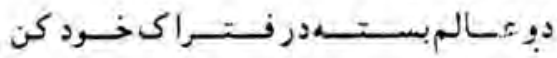

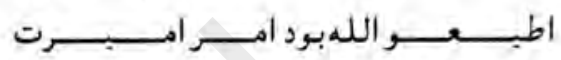

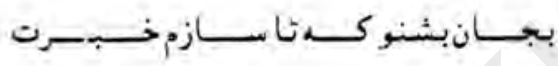

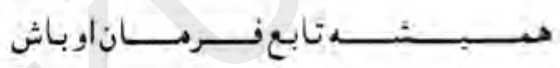

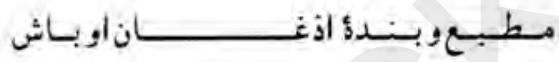

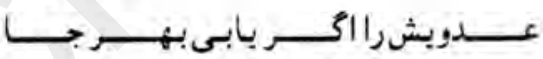

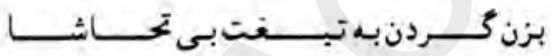

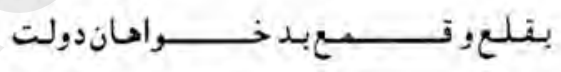

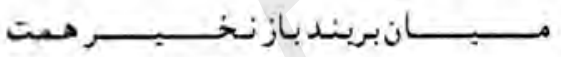

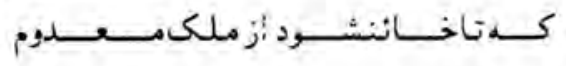

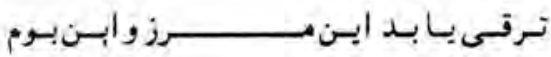

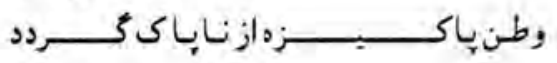

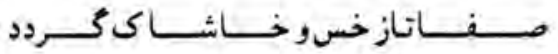




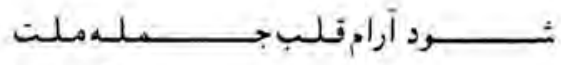

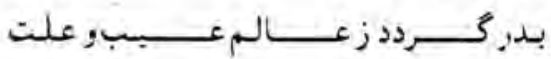

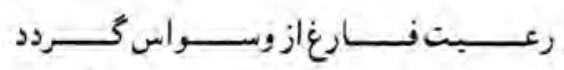

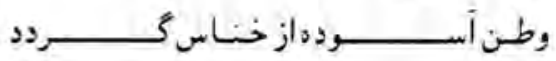

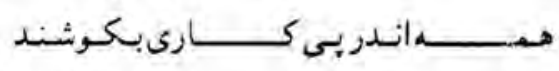

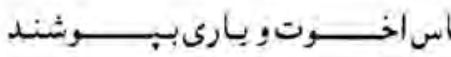

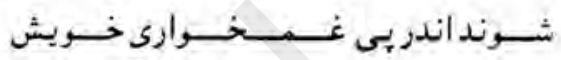

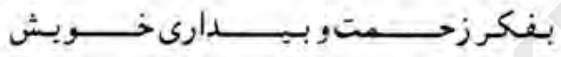

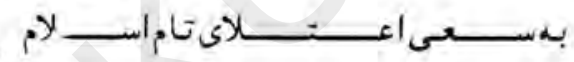

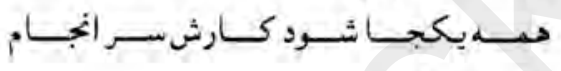

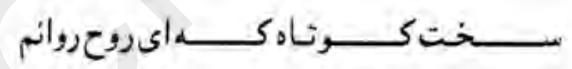

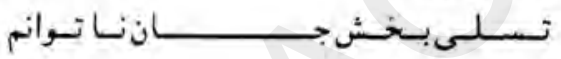

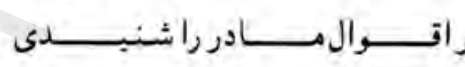

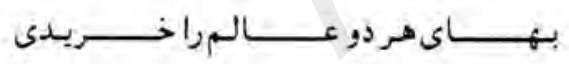

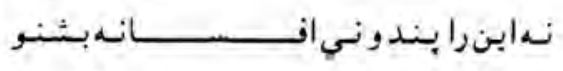

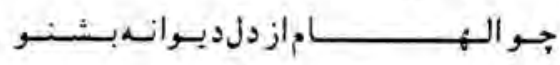

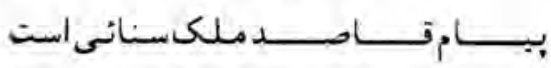

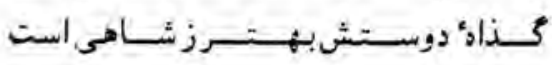




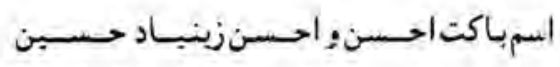

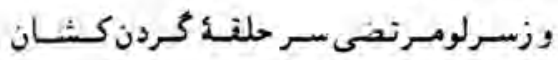

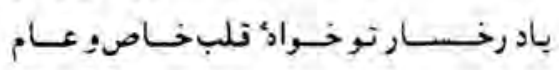

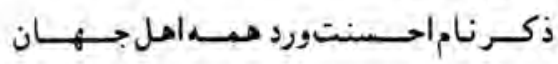

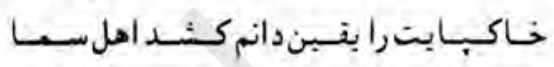

كحل ببينش سـرمـد سـامسرديدأكروز بيـان

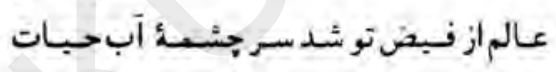

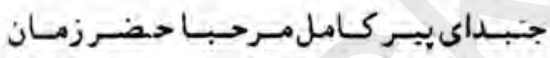

$$
\text { كر جهعنفـانىزيانهـا مسحودرمـدحنست }
$$

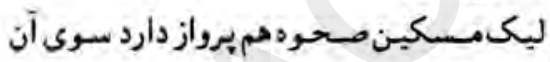

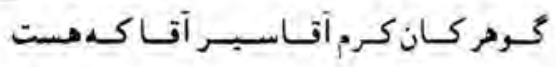

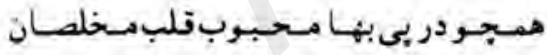

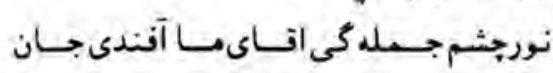

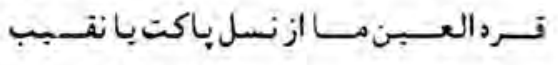

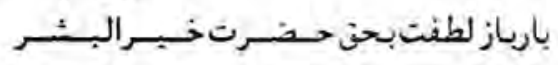

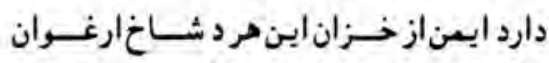

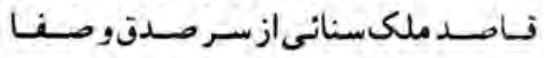

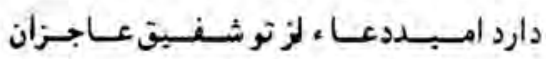




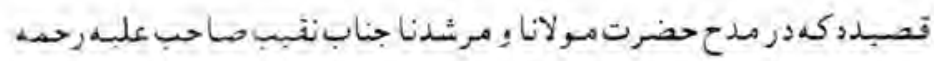

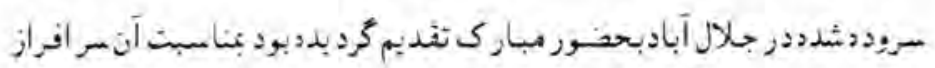

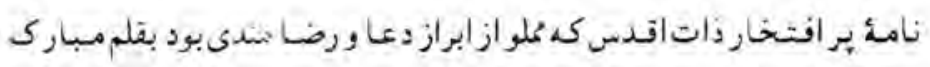
خود شانشرفوريد ارزانىنوده:

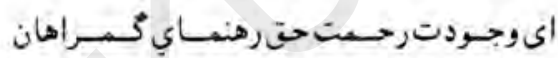

وى جســالت نور مطلق از رسـولانسورجـان:

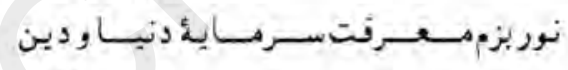

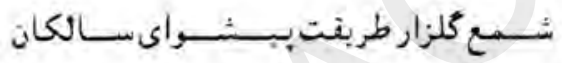

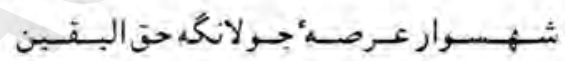

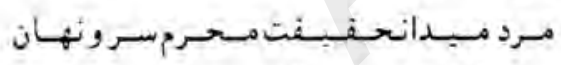

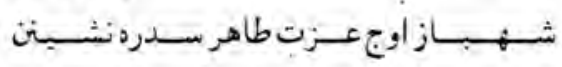

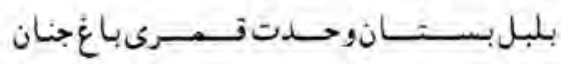

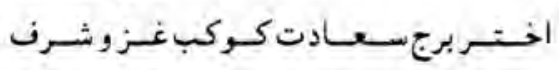

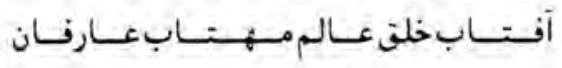




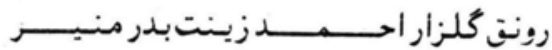

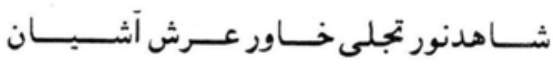

$$
\text { نسـبت قـــسى نشـانشـيخ عـبـدالقـادر است }
$$

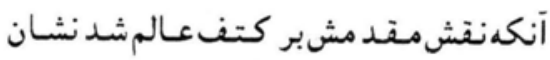

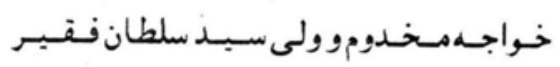

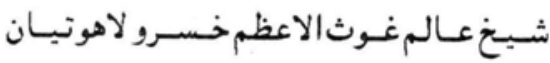

سـيـدعـالى نسب سمر دفـتــر ملك كـمـال

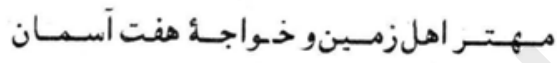

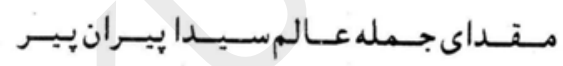

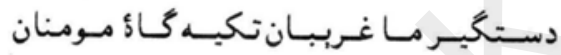

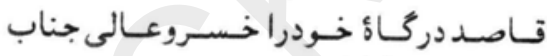

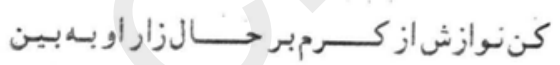




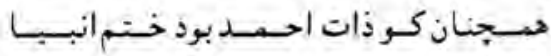

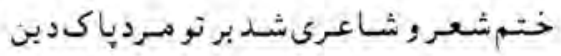

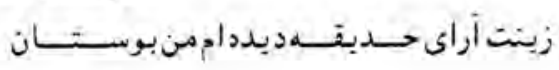

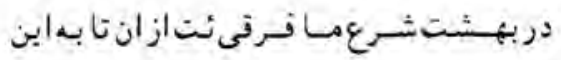

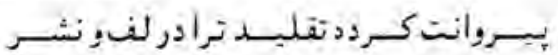

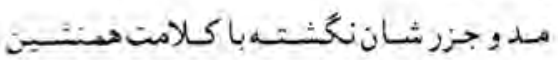

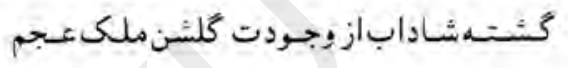

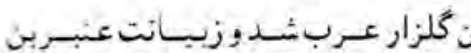

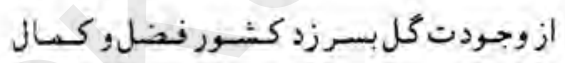

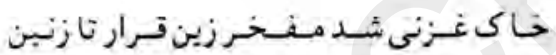

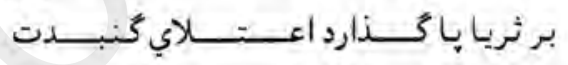

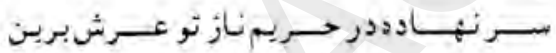

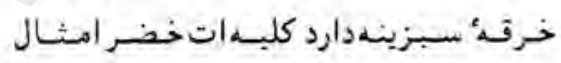

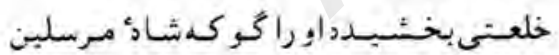

$$
\text { كى تواندفـصـر جنتهـــــــأروضـات }
$$

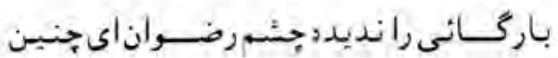

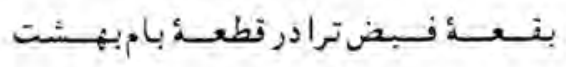

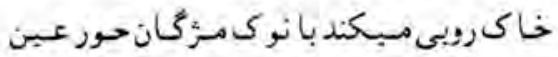




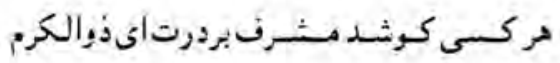

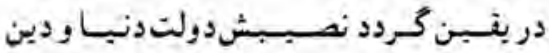

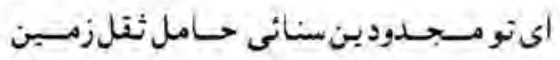

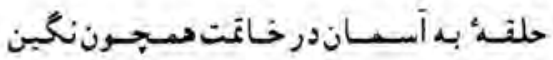

$$
\text { غـــوثربانى تيونى تطب مــدارتحت وفــوق }
$$

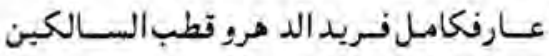

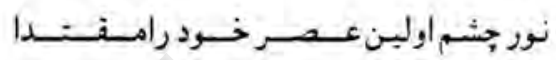

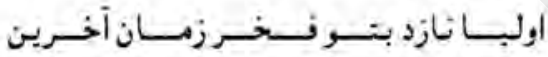

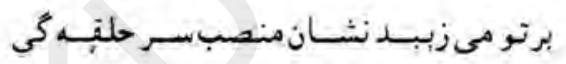

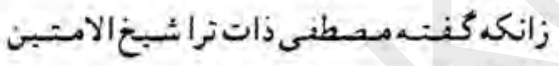

$$
\text { مقدمث بر فرقتبصر ناج فخر بئد كي است راست }
$$

كرد بايتخ

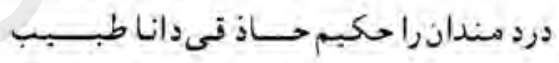

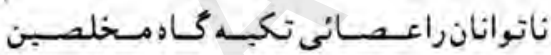

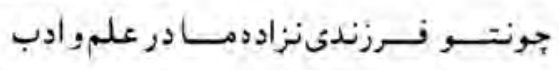

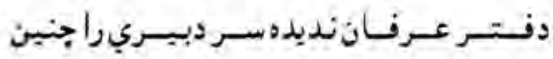

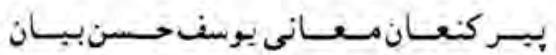

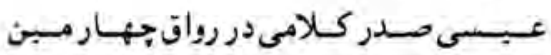


نظم نثــرترانديدمهـســــيدروزير جرخ

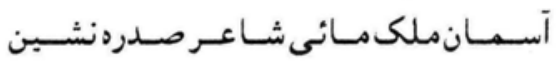

$$
\text { اهل مـــنى خـــرزند بـه بيــشت در ســـن }
$$

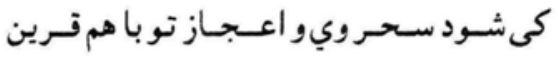

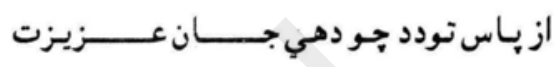

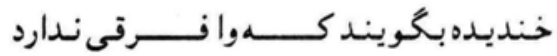

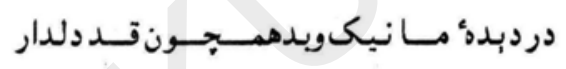

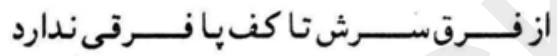

نى شـرمز بـد نامى وني نـنگو نه عـار است

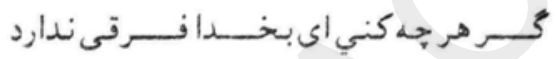

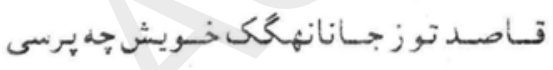

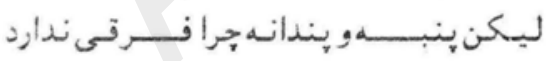




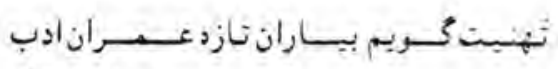

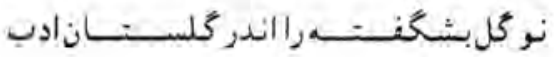

سعد و مبسون: مباركىباد بربينينباد نيكى

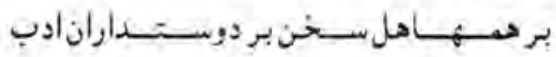

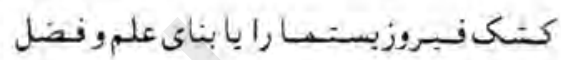

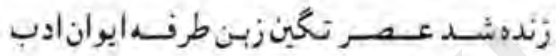

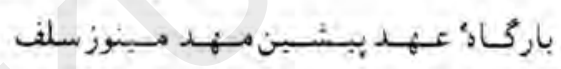
ياد وبودالمــــــود استور سـامــان ادب

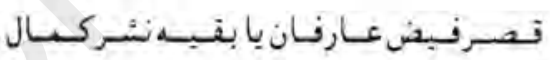

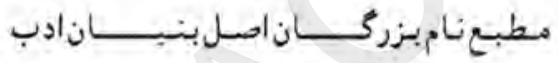

جلةُسبحان, حسبان جائفخر بوعلى است

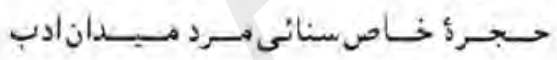

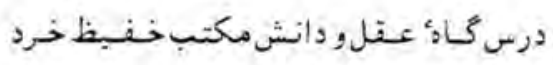

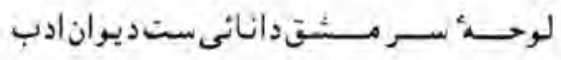

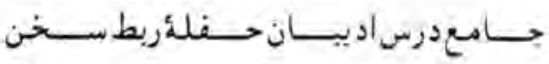

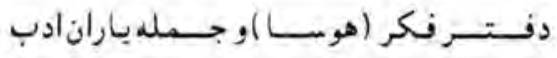




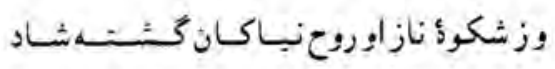

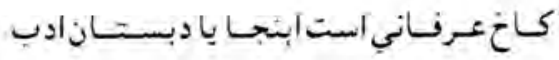

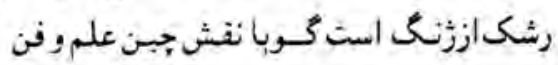

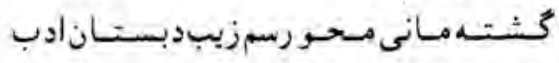

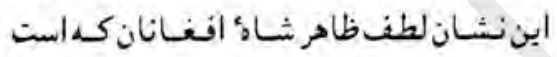

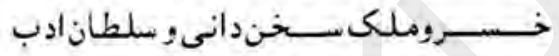




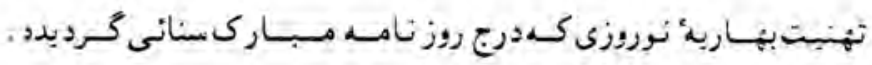

$$
\text { روز نوروزاست بارأنحلشكفت ازهركنار }
$$

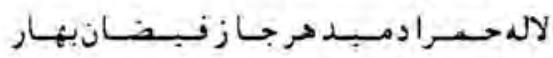

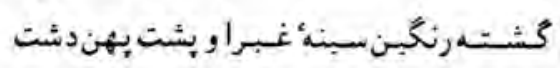

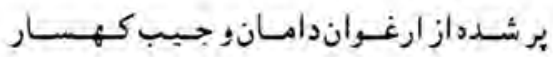

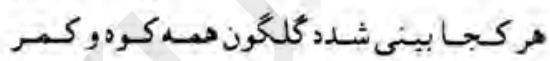

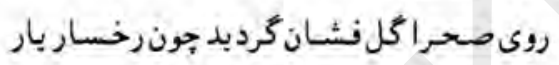

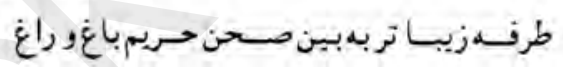

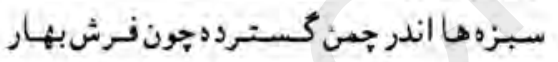

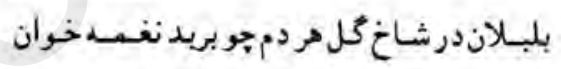

عندليبان خوش نوا شدبذلة كرو درشاخسار

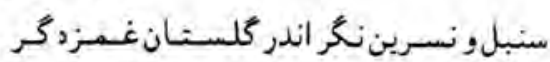

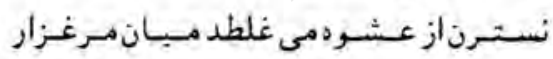

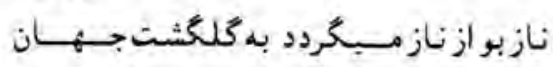

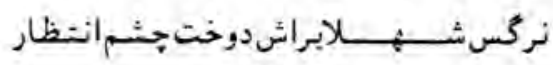

نو نهبالان جمله بوشـبـدهنبـاى صـونسبـز

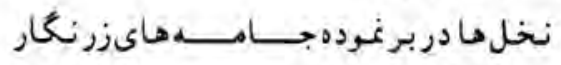




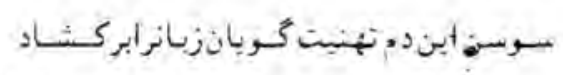

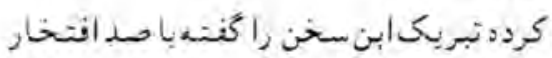

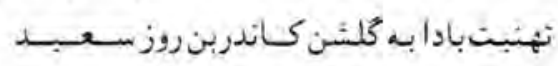

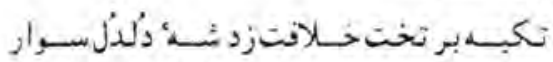

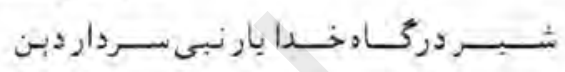

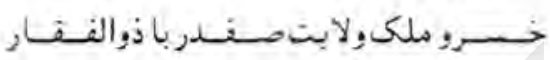

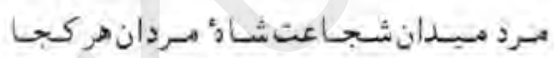

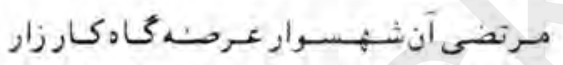

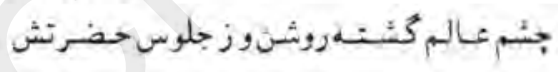

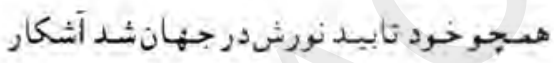

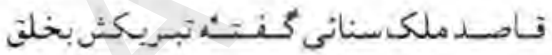

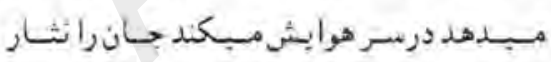




\section{بتاسبت سال هفدهم جشن استقلال وطن (از طبع فاصد سنانى)}

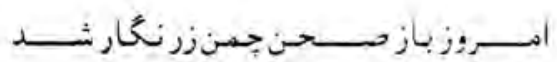

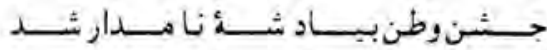

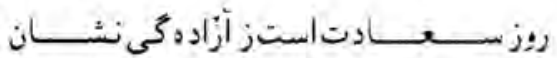

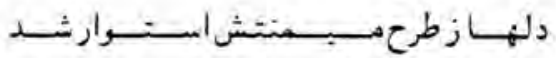

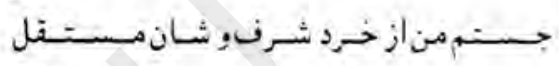

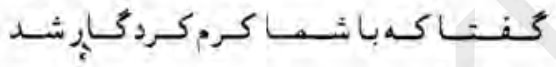

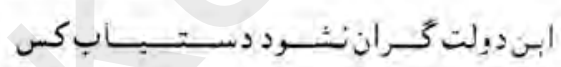

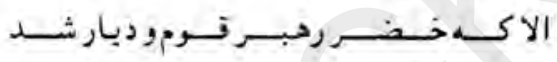

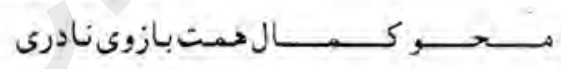

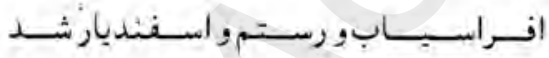

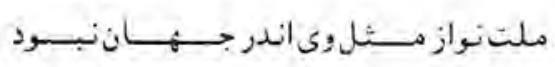

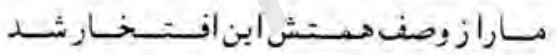

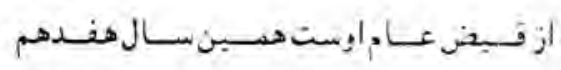

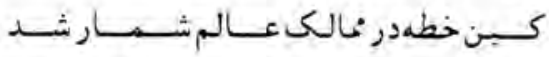

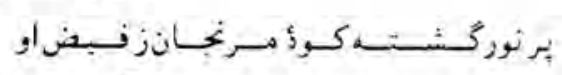

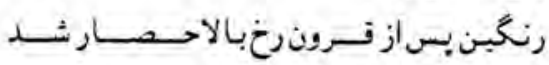




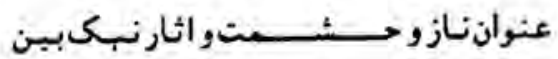

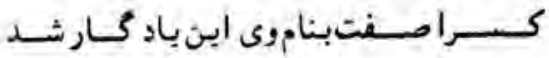

$$
\text { بكسـرنجـاتمــاودمـرطرفسه ياد كـار }
$$

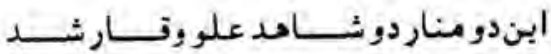

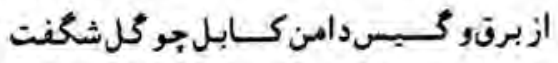

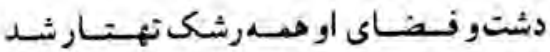

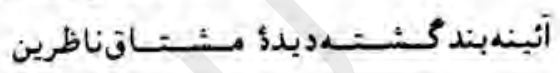

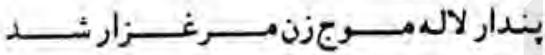

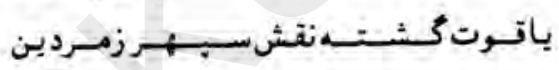

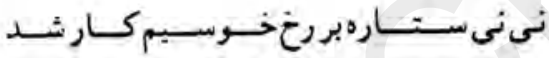

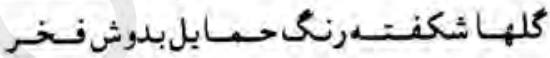

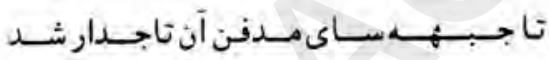

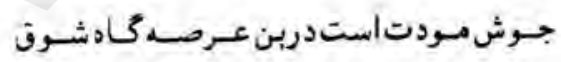

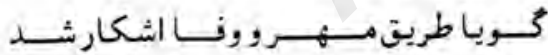

$$
\text { عـبش وســروز وخـرمى وشئادى هرطرف }
$$

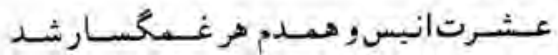

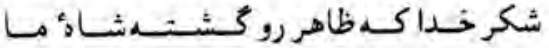

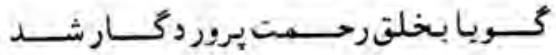




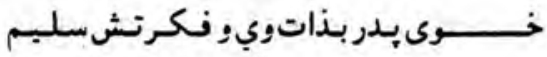

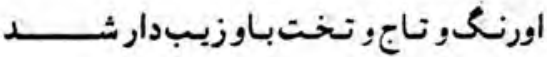

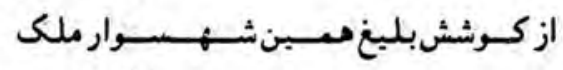

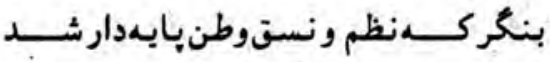

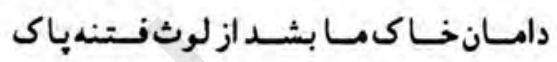

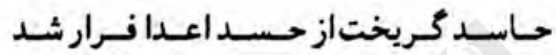

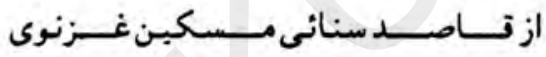

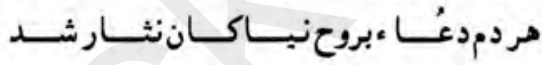




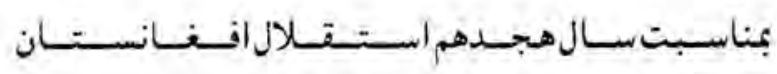

زفيض جشن استقلال ما صحن جمن أثبئه بندانشد

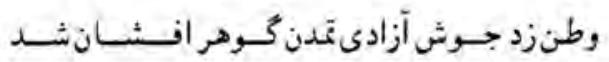

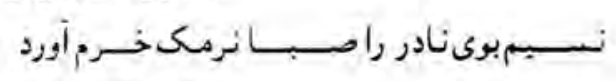

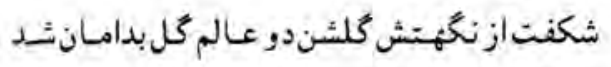

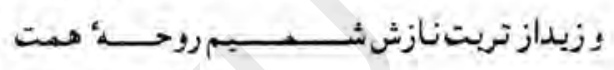

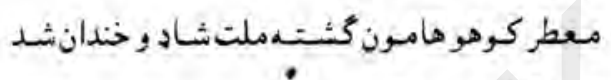

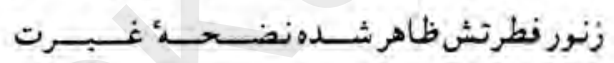

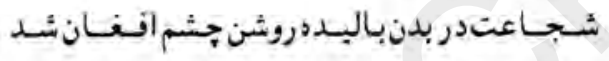

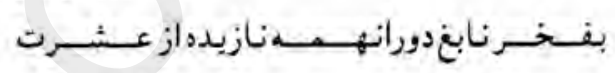

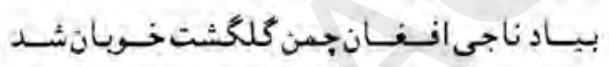

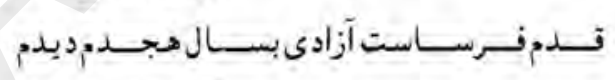

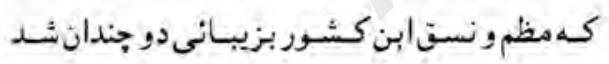

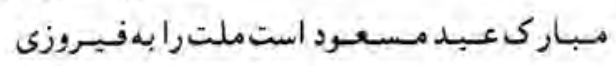

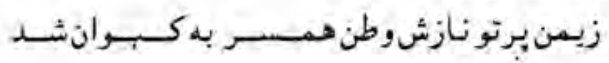

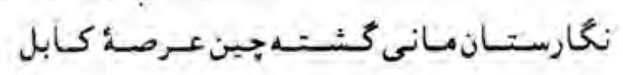

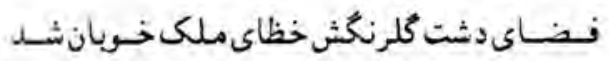




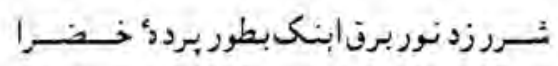

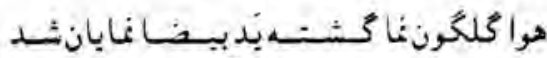

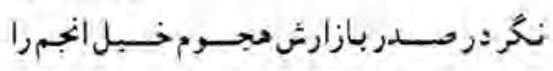

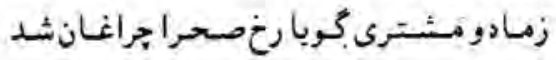

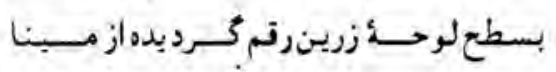

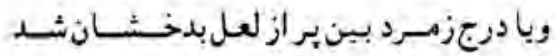

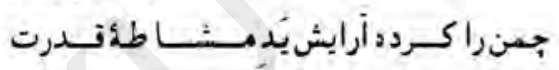

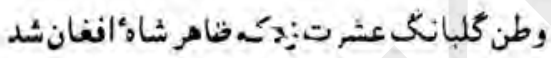

$$
\text { جولطف بسىنيـازىشـدنـرين ملتء إجـر وطن }
$$

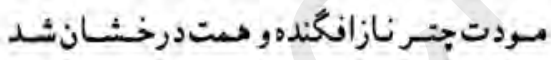

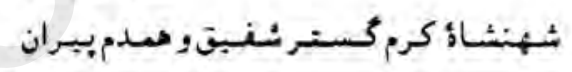

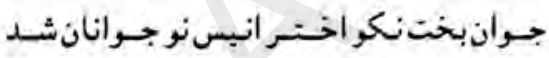

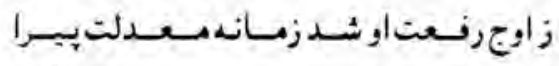

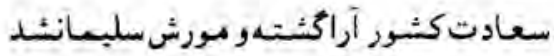

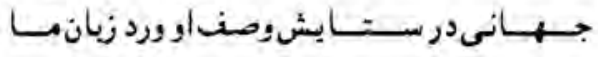

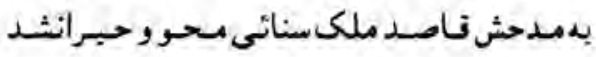




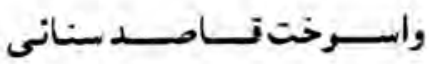

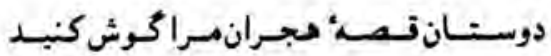

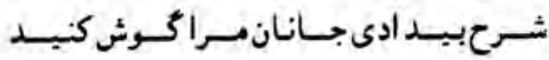

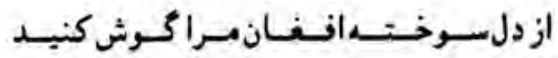

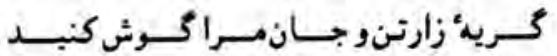

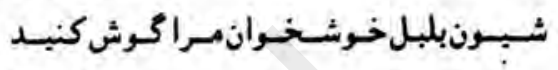

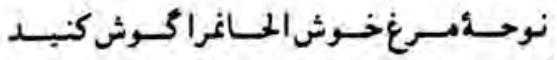

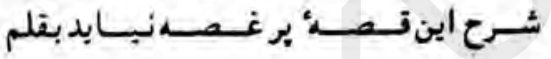

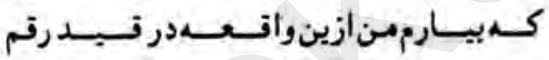

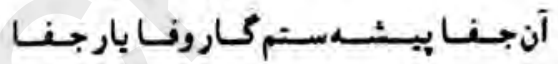

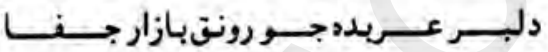

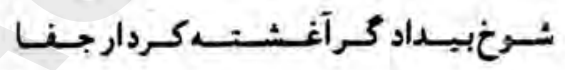

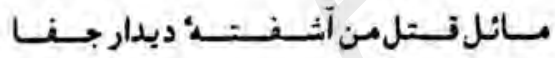

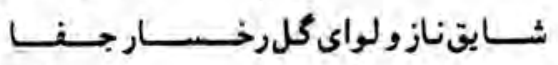

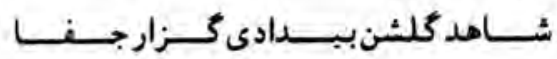

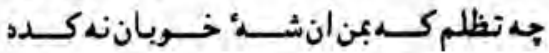

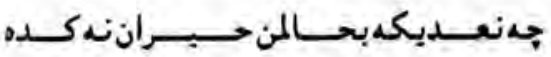




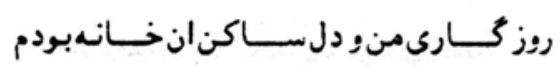

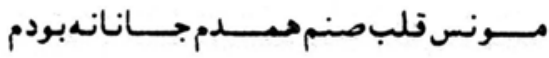

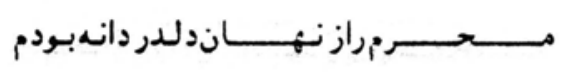

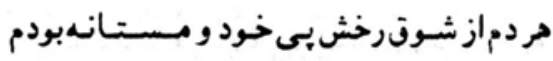

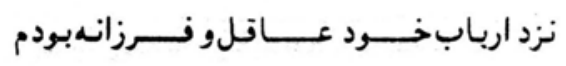

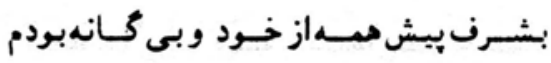

$$
\begin{aligned}
& \text { آخـر از جـور و جـفــايش بــــــان خـوار شـدم }
\end{aligned}
$$

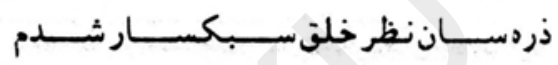

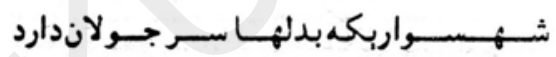

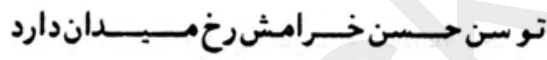

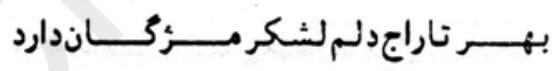

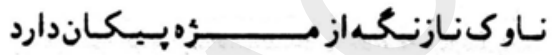

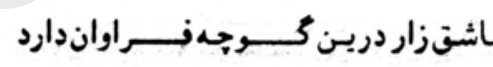

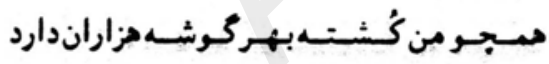

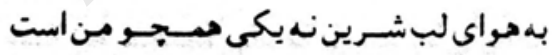

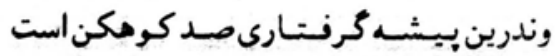

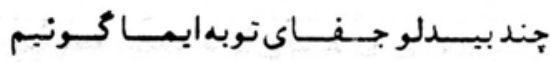

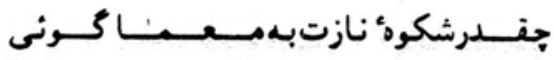




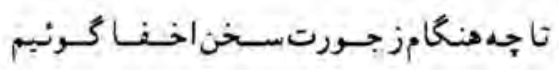

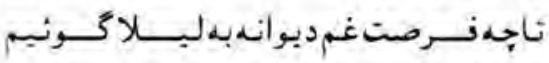

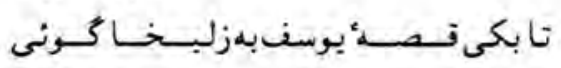

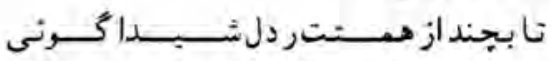

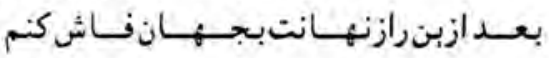

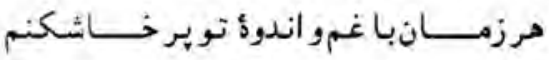

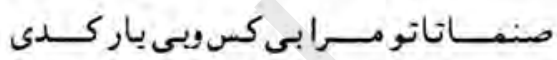

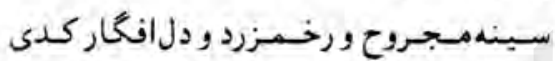

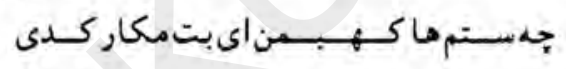

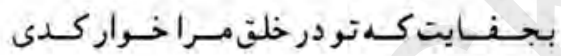

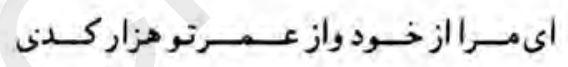

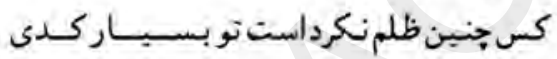

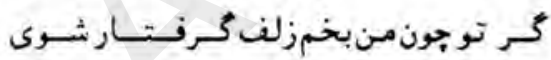

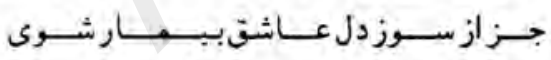

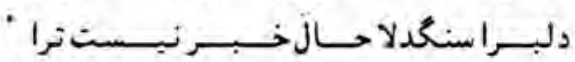

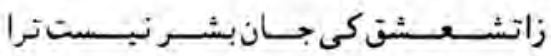

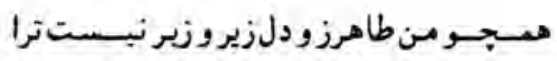

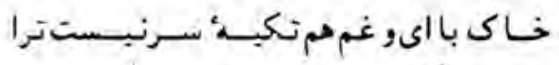




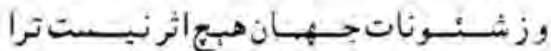

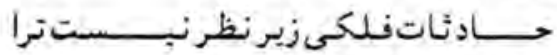

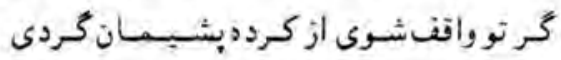

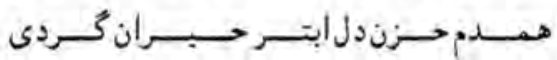

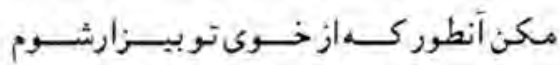

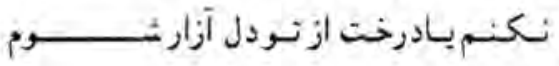

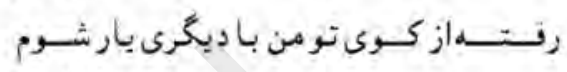

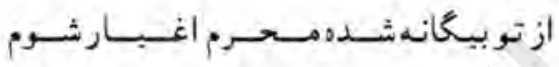

$$
\text { دل بدامدگ }
$$

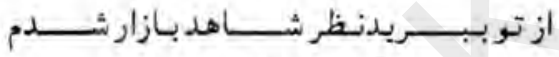

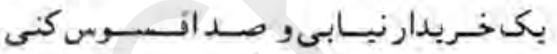

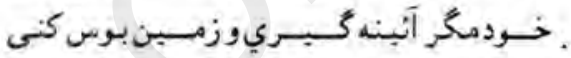

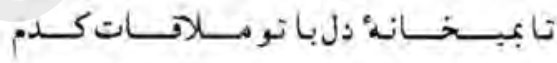

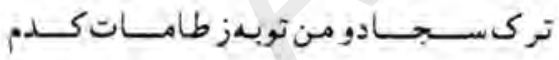

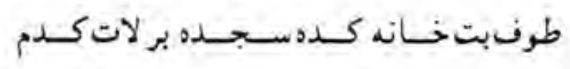

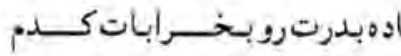

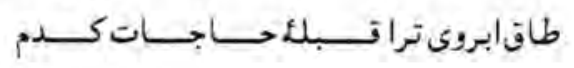

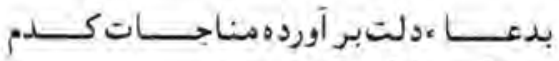

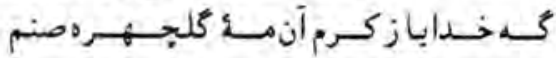

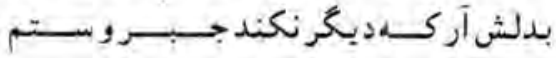




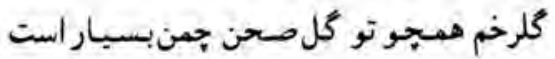

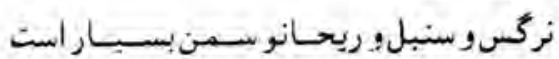

ني كهـ غـيـر از توبتىنبسيستبمنبسـبـار است

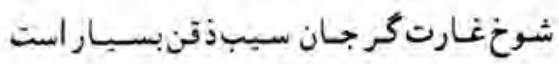

دلبـرى مـوى مسبـان غنتجـه دهن بسـبـار است

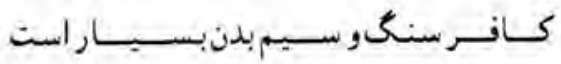

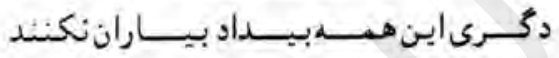

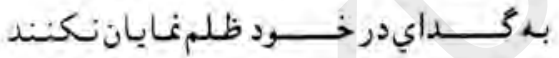

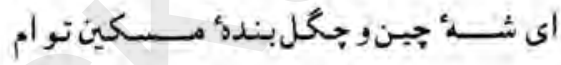

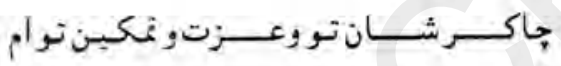

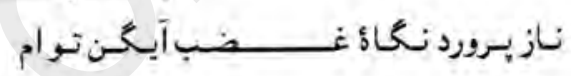

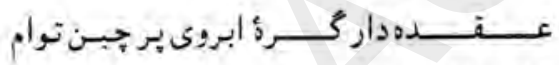

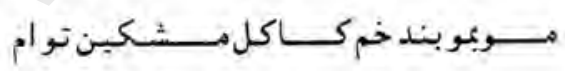

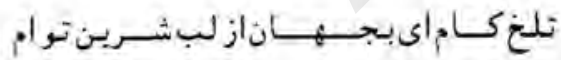

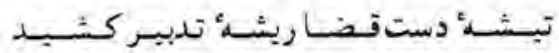

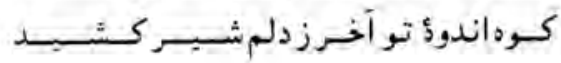




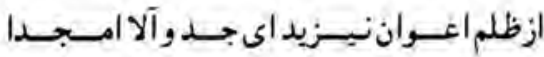

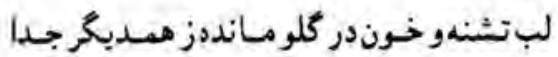

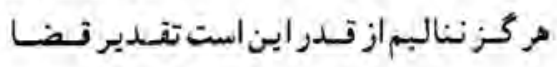

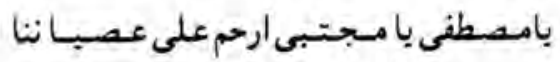

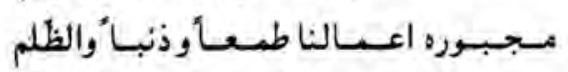

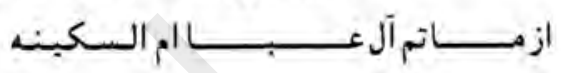

شـا فـاسمدامـاد راكردهز خـوندسيتش حنا

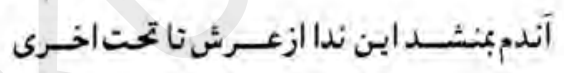

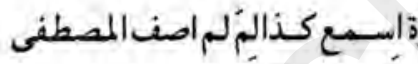

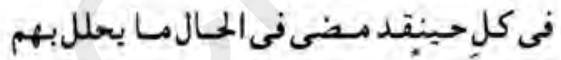

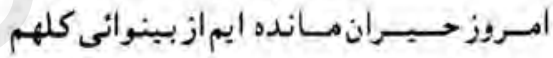

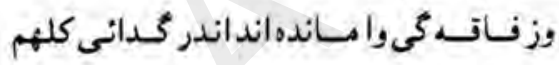

$$
\text { بارانجاكي وخون طبدجونمرغو ماثى كهم }
$$

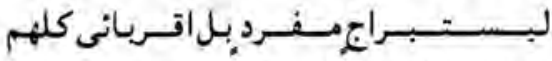

$$
\begin{aligned}
& \text { فى القبراشفع يا شفبع با الصـاد و النوثالقام }
\end{aligned}
$$

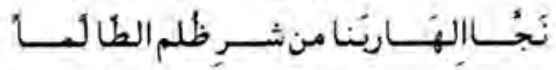

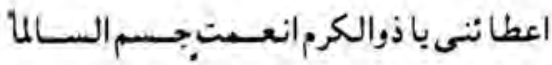




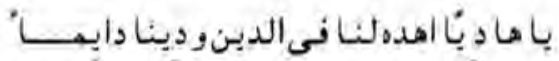

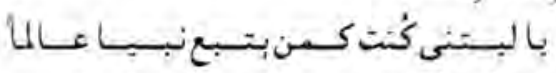

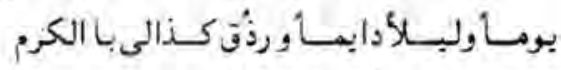

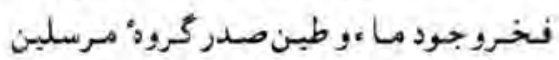

غــخوار روز وابسبن بنكر بحال اينكمين

ازذات باكت دريقبن دارم امـبـدى بسمتحسين

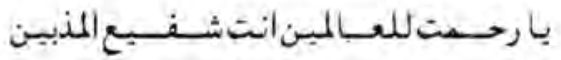

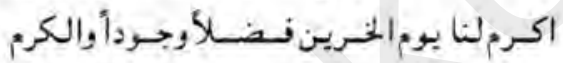

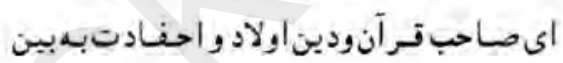

كزدست ظلم ظالمبن با مال غم خشت اجمعبين

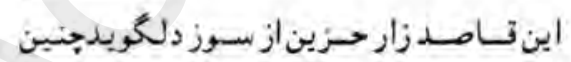

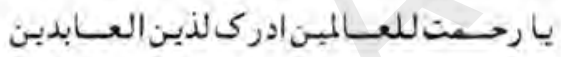

مسحبـوس ايدى الطالمينفى مبوكبو المذدهم 


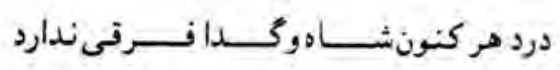

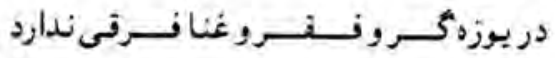

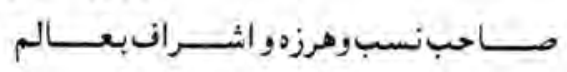

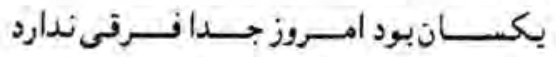

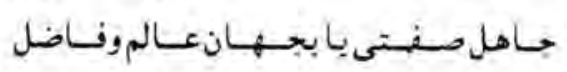

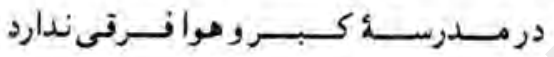

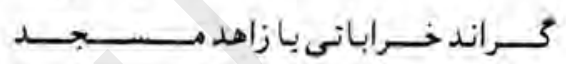

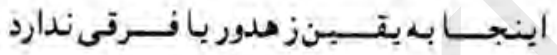

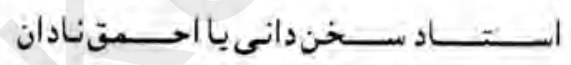

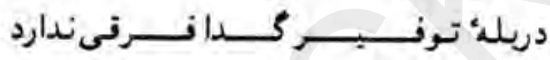

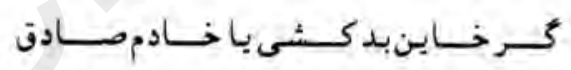

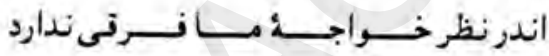

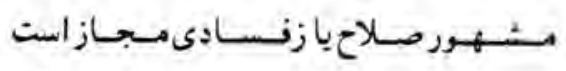

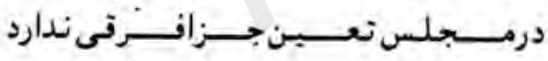

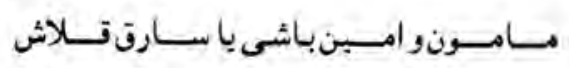

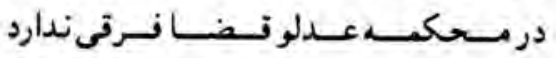




\section{خر مهـرهودرتهبمتوقتدرشهم يكرنى}

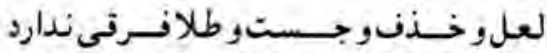

$$
\text { دربزم بزركــانكـــــاوب سـازوادبزاست }
$$

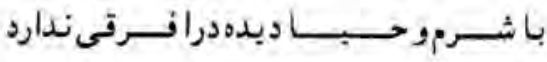

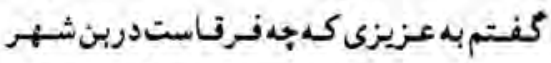

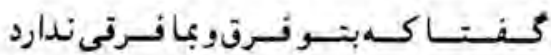

اين طرفم مسحبطى استكهدر عهـد وزمـانش

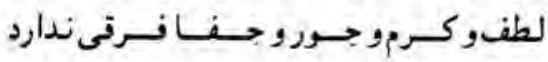




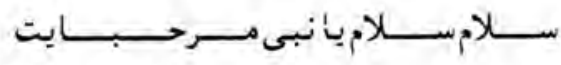

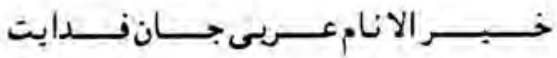

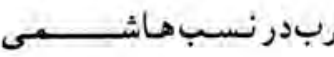

co

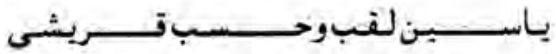

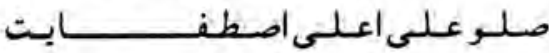

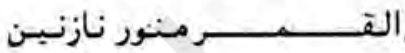

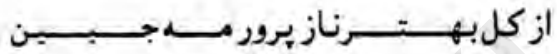

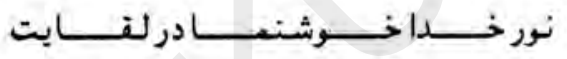

مـانهـ

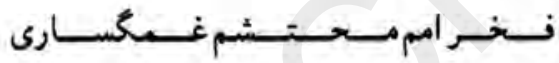

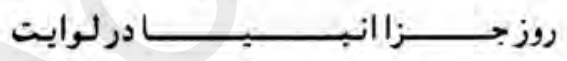

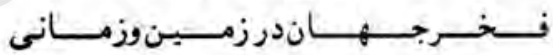

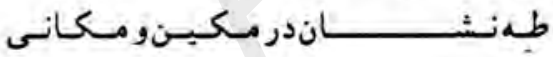

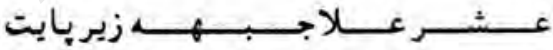

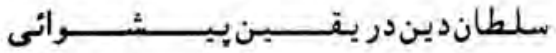

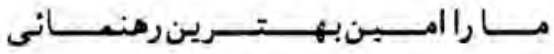

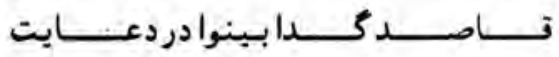




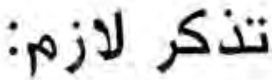

در رحلت روان شاد حضرت ((قاصد سنائى)) عليه الرحمه همه

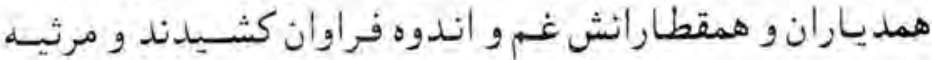

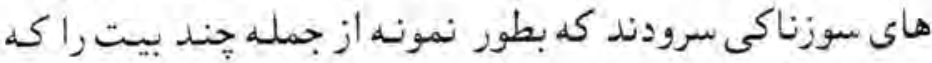
مرحوم حاكم عبد الوهـاب خان مغفور دور ورثايث انشيـاد فرمسوده

$$
\text { اتد مى آوريمج }
$$

وا حسرتا كه قاصد ما أز جهان برفت

شور و فغانهاست كه تا آسمان برفت

$$
\text { او بود بيك حضرت مجدود سنائى }
$$

صد حيف آن وجو: كزين دودمان بردين برفت

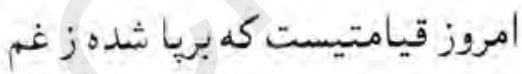

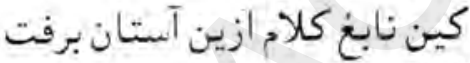

$$
\text { در نه برج حوت خرد كفت سال فوت }
$$

مغفور جو ورا كه بدين عز و شان برفت

كه از بيـت اخير سـال رحلت قـاصد صـاحب مرحوم استخراج

PERY F

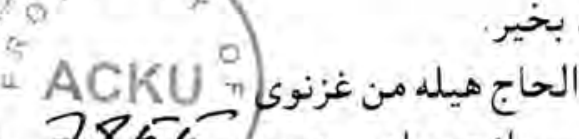

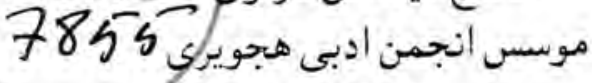

فبرورى 1999 يثباور

91

$$
\text { ميخر }
$$

$$
\text { والسلام تمام شدد بخير. }
$$

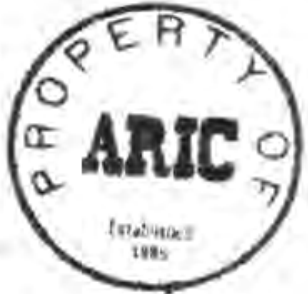


جاب: دانش كتابخانه، تصه خوانى بازار- بببنور تبلفون: 2564513 